\title{
Personal Control of the Indoor Environment in Offices: Relations with Building Characteristics, Influence on Occupant Perception and Reported Symptoms Related to the Building-The Officair Project
}

\author{
Ioannis Sakellaris ${ }^{1, *} * \mathbb{D}$, Dikaia Saraga ${ }^{1,2} \mathbb{D}^{\circ}$, Corinne Mandin ${ }^{3}\left(\mathbb{C}\right.$, Yvonne de Kluizenaar ${ }^{4}$, \\ Serena Fossati ${ }^{5}$, Andrea Spinazzè ${ }^{6}{ }^{\mathbb{D}}$, Andrea Cattaneo ${ }^{6}(\mathbb{D})$, Tamas Szigeti ${ }^{7}$, Victor Mihucz ${ }^{7}$, \\ Eduardo de Oliveira Fernandes ${ }^{8}$, Krystallia Kalimeri ${ }^{1}{ }^{(1)}$, Paolo Carrer ${ }^{9}(\mathbb{C})$ and John Bartzis ${ }^{1, *}$ \\ 1 Department of Mechanical Engineering, University of Western Macedonia, Sialvera \& Bakola Str., \\ 50100 Kozani, Greece \\ 2 Environmental Research Laboratory, INRASTES, National Center for Scientific Research "DEMOKRITOS", \\ Aghia Paraskevi Attikis, P.O. Box 60228, 15310 Athens, Greece \\ 3 Université Paris Est, CSTB-Centre Scientifique et Technique du Bâtiment, 84 avenue Jean Jaurès, \\ 77447 Marne-la-Vallée CEDEX 2, France \\ 4 The Netherlands Organization for Applied Scientific Research (TNO), P.O. Box 96800, \\ 2509 JE The Hague, The Netherlands \\ 5 ISGlobal, Institute for Global Health, 08036 Barcelona, Spain \\ 6 Department of Science and High Technology, University of Insubria, Via Valleggio 11, 22100 Como, Italy \\ 7 Cooperative Research Centre for Environmental Sciences, Eötvös Loránd University, Pázmány Péter sétány \\ 1/A, H-1117 Budapest, Hungary \\ 8 Institute of Science and Innovation in Mechanical Engineering and Industrial Management, \\ Rua Dr. Roberto Frias s/n, 4200-465 Porto, Portugal \\ 9 Department of Biomedical and Clinical Sciences-Hospital “L. Sacco”, University of Milan, via G.B. Grassi 74, \\ 20157 Milano, Italy \\ * Correspondence: isakellaris@uowm.gr (I.S.); bartzis@uowm.gr (J.B.); Tel.: +30-246-105-6710 (J.B.)
}

Received: 11 July 2019; Accepted: 5 August 2019; Published: 7 August 2019

check for updates

\begin{abstract}
Personal control over various indoor environment parameters, especially in the last decades, appear to have a significant role on occupants' comfort, health and productivity. To reveal this complex relationship, 7441 occupants of 167 recently built or retrofitted office buildings in eight European countries participated in an online survey about personal/health/work data as well as physical/psycho-social information. The relationship between the types of control available over indoor environments and the perceived personal control of the occupants was examined, as well as the combined effect of the control parameters on the perceived comfort using multilevel statistical models. The results indicated that most of the occupants have no or low control on noise. Half of the occupants declared no or low control on ventilation and temperature conditions. Almost one-third of them remarked that they do not have satisfactory levels of control for lighting and shading from sun conditions. The presence of operable windows was shown to influence occupants' control perception over temperature, ventilation, light and noise. General building characteristics, such as floor number and floor area, office type, etc., helped occupants associate freedom positively with control perception. Combined controlling parameters seem to have a strong relation with overall comfort, as well as with perception regarding amount of privacy, office layout and decoration satisfaction. The results also indicated that occupants with more personal control may have less building-related symptoms. Noise control parameter had the highest impact on the occupants' overall comfort.
\end{abstract}

Keywords: IEQ; perceived comfort; sick building syndrome; health effects 


\section{Introduction}

Office employees spend a significant part of their time in modern office buildings that are characterized by sealed facades and complex building systems (e.g., mechanical, electrical, plumbing, controls and fire protection systems) designed to reduce energy costs through controlled indoor environment conditions. Beside central control, a wide range of degrees of personal control, such as local thermostats, windows, personal lights etc., over the indoor environment can be found in modern office buildings. Personal control has a crucial role in achieving a healthy [1-3], comfortable [4-7] and productive [8-11] environment, reducing energy consumption in buildings without sacrificing the comfort of occupants $[12,13]$. The effect of personal control on occupant satisfaction, especially with regards to providing well-being and comfort is an important area of study $[14,15]$.

Several studies have focused on estimating occupants' comfort in offices and the ability to control indoor environment parameters, producing a better Indoor Environment Quality (IEQ). In 1990, Paciuk [16] studied if indoor environment comfort was affected by personal control, leading to a model using thermal control parameters. Three different types of control parameters were involved: available control (the degree and type of control made available by the environment), exercised control (the relative frequency in which occupants engage in several types of controls to obtain comfort) and perceived control (how the different degrees of available and exercised control interact to produce different levels of perceived control). The model was applied on data from ten offices ( 511 workstations). The results pointed out that the occupants' level of control perception at their workstation enhances their satisfaction in their working environment.

The possibility to control light satisfaction was surveyed by Collins et al. [17] in 13 office buildings. The occupants provided with a task light recorded in general a higher satisfaction with light comfort than those without a task light. In addition, both groups expressed improved light satisfaction when they had the possibility to control light conditions. In another study [18], the role of personal control in natural versus mechanical ventilated office buildings was investigated. Personal control on operable windows, electronic lightning and solar blinds in natural ventilated buildings resulted in higher levels of perceived control. It was also mentioned that control systems should be simple and in compliance with the building design, as well as with quick response to alleviate discomfort as soon as it is experienced. The level of perceived control by occupants had a small influence on the indoor environment satisfaction, as described by Haghighat and Donnini [19] through a survey in 12 office buildings. Satisfaction with respect to temperature, air quality, ventilation, air circulation and overall comfort showed a moderate correlation with perceived control. On the contrary, there was a decline in prevalence of health symptoms with an increasing amount of control over the indoor environment.

The association of temperature personal control and operable windows with reported health symptoms and complaints was indicated in the early 1990s [20]. Many years later, Toftum [21] examined occupants' comfort perception and symptoms prevalent in mechanical versus natural ventilated buildings in 24 office buildings located in Denmark. Multiple logistic regression analysis indicated that the perceived control was more important for the prevalence of symptoms and environment perception than the type of ventilation.

Zagreus et al. [22] remarked that occupants with a sense of high degree of control over environmental parameters such as temperature, air movement, air quality and noise, were more satisfied with the indoor environment. Boerstra et al. [23] examined the impact of perceived control and access to control options in occupants' health and comfort, through 64 office buildings in Europe. The link between perceived comfort and control parameters such as temperature, ventilation, shading from the sun, light, noise was investigated. The analysis showed that occupants feel more comfortable when the perceived control over temperature, ventilation and noise is high. No significant correlation was found between comfort and the different types of access to control like operable windows, type of thermostats, etc., except for solar radiation.

In a recent study, Kwon et al. [24] tried to identify the relationship between the level of personal control and users satisfaction within offices. They found that higher controllability leads to more 
thermal and visual satisfaction, while the results revealed the psychological impact on the users' satisfaction by indicating differences among the available control types. The psychological aspect in personal control was also raised by Luo and Cao [25] and Karjalainen [26].

The physiological and psychological aspect of IEQ satisfaction [27] and more specific thermal satisfaction makes it harder to control indoor environment conditions and provide optimal results for everyone in a given space. The ASHRAE standard $55[27,28]$ or ISO $7730[29,30]$ tries to give a solution in this complex relation by stating the appropriate conditions that should be met in order to establish comfort levels in offices. To achieve that, these standards consider both personal factors, such as metabolic rate and clothing level, and environmental factors, such as air temperature, mean radiant temperature, air speed and humidity. Apart from thermal comfort, other factors that can influence comfort levels are usability of a space, acoustics, ventilation, daylight and energy use in a building.

Literature review highlights the role of personal control on the IEQ in office buildings. The objective of this paper is to provide an updated overview of the personal control in office buildings and the association with occupants' perception. To the best of our knowledge, this is the first time that European employees have participated in a questionnaire survey covering simultaneously in detail records of comfort, control and health perception in office buildings. This large-scale survey was performed under the framework of the European FP7-funded project OFFICAIR [31] and included eight widely distributed across European countries (Finland, France, Greece, Hungary, Italy, Portugal, Spain, The Netherlands) with different characteristics (e.g., geographical location, climate, socio-economic status). More specifically, the aim of this study is threefold: (i) to describe the degree of personal control over indoor environments in office buildings as reported by occupants (perceived personal control) and the association with access to available controls; (ii) to investigate the associations between perceived control and building characteristics; (iii) to study the associations between perceived control and perceived comfort and health of the occupants.

\section{Materials and Methods}

\subsection{Data Collection}

This study is based on data collected between October 2011 and May 2012 in the OFFICAIR project in modern office buildings in eight European countries [32-40]. 'Modern' buildings, constructed during the last 10 years, are described by the presence of several sorts of new electronic equipment and ventilation, heating and cooling systems, making the indoor environment almost unaffected by local climate [34]. About 19 to 24 modern buildings, selected on a voluntary basis, were investigated per country, resulting in 167 office buildings.

The protocol for data collection is described elsewhere in detail [34]. After a preliminary inspection of each building, a checklist was filled in by a local investigator along with a building manager, gathering information about building characteristics (e.g., presence of solar devices, operable windows), mechanical systems (e.g., type of mechanical ventilation, heating, cooling), rooms and activities (e.g., type of work, cleaning schedules). An online survey for the building occupants was developed in the national language of the participating countries and included questions on personal control of the indoor environment as perceived by the occupant, perceived comfort and building-related symptoms. The survey was anonymous and the participants gave their consent prior to participation. The study was approved by the competent local/national ethics committees. In total, 26,735 email invitations were sent to the occupants with an average response rate of $41 \%$ across the buildings. Although the questionnaire was online and its length might have influenced the response rate, the participation rate can be considered satisfying, in line with other recent surveys [34]. The final database involved 7441 participants- $52 \%$ were females and $48 \%$ were males with an average age of 41 years. 


\subsection{Characteristics of the Buildings and Access to Control}

The available control types in each office building were obtained from the OFFICAIR checklist (details in Table 1). The checklist included information regarding the presence of solar shading devices (grouped as: not present, internal, external), type of solar shading device control, type of temperature control, presence of operable windows, type of main lights control and type of mechanical ventilation control.

Table 1. Checklist used to investigate the types of controls over the indoor environment available for occupants in the building in the OFFICAIR project.

\begin{tabular}{|c|c|}
\hline Parameter & Items \\
\hline $\begin{array}{l}\text { Are there solar shading devices present? } \\
\text { Which kind? }\end{array}$ & $\begin{array}{c}\text { Not present } \\
\text { South side only } \\
\text { One or more other facades } \\
\text { External vertical blinds } \\
\text { External shutters } \\
\text { External roller shutters } \\
\text { External louvers } \\
\text { External screens } \\
\text { External window films } \\
\text { External horizontal blinds } \\
\text { External awnings/canopies } \\
\text { External overhangs } \\
\text { External vertical fins } \\
\text { Blind between glazing } \\
\text { Internal vertical blinds } \\
\text { Internal louvers } \\
\text { Atrium } \\
\text { Double façade } \\
\text { Other }\end{array}$ \\
\hline How are the solar shading devices controlled? & $\begin{array}{l}\text { No control (fixed) } \\
\text { Individual } \\
\text { Central down, individual up } \\
\text { Automatic }\end{array}$ \\
\hline How is the room temperature controlled? & $\begin{array}{c}\text { Manual radiator valve } \\
\text { Local thermostat at radiator/heating unit } \\
\text { Local thermostat (e.g., on wall) } \\
\text { Central sensor } \\
\text { Façade sensor(s) - i.e., outside temperature } \\
\text { Zone sensor(s) } \\
\text { Manual control in room(s) } \\
\text { According to occupancy } \\
\text { Other }\end{array}$ \\
\hline Are the windows operable? & $\begin{array}{c}\text { Yes } \\
\text { Yes, some } \\
\text { Yes, but occupants are not allowed to open them } \\
\text { No }\end{array}$ \\
\hline $\begin{array}{l}\text { How are main lights (e.g., ceiling or wall) } \\
\text { controlled? }\end{array}$ & $\begin{array}{c}\text { Automatic by time (building/floor/zone) } \\
\text { Automatic with manual end control (building/floor/zone) } \\
\text { Demand control: Daylight (photocells) } \\
\text { Demand control: Occupants (motion sensors) } \\
\text { Manual }\end{array}$ \\
\hline $\begin{array}{l}\text { What type of control system is there for } \\
\text { mechanical ventilation? }\end{array}$ & $\begin{array}{c}\text { Central-Manual (on/off) } \\
\text { Central—Clock/Central-Demand control (temperature, } \\
\mathrm{CO}_{2} \text {, other pollutant, relative humidity) } \\
\text { Local-Manual (on/off) } \\
\text { Local-Clock/Local-Demand control } \\
\text { (temperature, } \mathrm{CO}_{2} \text {, other pollutant, relative humidity) } \\
\text { Recirculation control }\end{array}$ \\
\hline
\end{tabular}




\subsection{Perceived Control over the Indoor Environment}

Five controlling parameters were set for defining the occupants' evaluation of the perceived control and IEQ: Personal control of the occupants over temperature, ventilation, shade from the sun, light and noise was investigated using the following question with a seven-point Likert-like scale answer (from "1, not at all" to "7, full control"): 'How much control do you personally have over the following aspects of your working environment?'. The combined control variables were introduced. Several combinations were used (e.g., perceived control over temperature and ventilation) and the overall combined control variable containing all the 5 parameters [23].

\subsection{Personal Comfort, Reported Health Symptoms and Self-Assessed Productivity}

The satisfaction of the occupants toward the following parameters was evaluated: overall comfort, temperature (overall, too hot/cold, variation), air movement, air quality (overall air quality satisfaction, humid or dry air, stuffy or fresh air, odor), light (overall light satisfaction, natural, artificial, glare), noise (overall noise satisfaction, outside noise, noise from building systems, noise within the building), vibration, amount of privacy, office layout, office decoration, and view from the windows. The following question was used: 'How would you describe the typical indoor conditions in your office environment during the past month?' or 'How would you describe the following in your office?' A seven-point Likert-like scale answer (from " 1 , dissatisfied" to "7, satisfied") was provided for most of the questions, except for those questions investigating two extreme conditions in contrast where a seven-point scale answer ranging from -3 to 3 was adopted (Table 2) and converted to a scale from 1 to 7 as follow: $+/-3=1 ;+/-2=3 ;+/-1=5 ; 0=7$.

Table 2. Questions used to investigate occupants' indoor environment quality perception in the OFFICAIR project.

\begin{tabular}{|c|c|c|}
\hline Parameter & Sub-Parameters & Type of Answer \\
\hline \multirow{4}{*}{$\begin{array}{l}\text { Overall Comfort } \\
\text { Temperature }\end{array}$} & \multirow{2}{*}{ Overall temperature } & Seven-point Likert-like scale \\
\hline & & Seven-point Likert-like scale \\
\hline & Too hot/too cold temperature & From " -3 , too hot" to " +3 , too cold" \\
\hline & Temperature variation & From " -3 , too much" to " +3 , not enough" \\
\hline \multirow{5}{*}{$\begin{array}{l}\text { Air movement } \\
\text { Air quality }\end{array}$} & & From " -3 , too draughty" to " +3 , too still" \\
\hline & Overall air quality & Seven-point Likert-like scale \\
\hline & Humid/dry air & From " -3 , too humid" to " +3 , too dry" \\
\hline & Stuffy or fresh air & Seven-point Likert-like scale \\
\hline & Odor & Seven-point Likert-like scale \\
\hline \multirow[t]{4}{*}{ Light } & Overall light & Seven-point Likert-like scale \\
\hline & Natural & Seven-point Likert-like scale \\
\hline & Artificial & Seven-point Likert-like scale \\
\hline & Glare & Seven-point Likert-like scale \\
\hline \multirow[t]{4}{*}{ Noise } & Overall noise & Seven-point Likert-like scale \\
\hline & Outside noise & Seven-point Likert-like scale \\
\hline & Noise from building systems & Seven-point Likert-like scale \\
\hline & Noise within the building & Seven-point Likert-like scale \\
\hline Vibration & & Seven-point Likert-like scale \\
\hline Amount of privacy & & Seven-point Likert-like scale \\
\hline Office layout & & Seven-point Likert-like scale \\
\hline Office decoration & & Seven-point Likert-like scale \\
\hline View from the windows & & Seven-point Likert-like scale \\
\hline
\end{tabular}

The occupants were also requested to estimate their productivity at the workstation and in other locations inside the building, considering the influence of environmental conditions on a scale of 7 levels, from $+30 \%$ to $-30 \%$. In addition, they were requested to record building-related health symptoms. The Personal Symptom Index-5 (PSI-5) was calculated based on the incidence of five health symptoms - dry eyes, blocked or stuffy nose, dry throat, headache, and tiredness-which 
are considered to be the fundamental components of sick building symptoms as mentioned by Raw et al. [41]. This indicator has a 0 to 5 score, according to the prevalence of the reported symptoms. The respective question was: 'Have you ever experienced any of the following symptoms while working in this building (or workstation) (including today)?'

\subsection{Statistical Analysis}

The statistical analysis of the dataset was performed in four steps (Figure 1):

i. Descriptive results were obtained.

ii. The correlation between the available control and the perceived control using the Kruskal Wallis analysis of variance test was investigated [23,42]. Groups with less than five individuals were not included in the analysis.

iii. The relationship between the occupants' overall combined perceived control and the general physical building characteristics as well as the occupant personal characteristics was examined by applying a multilevel model $[43,44]$, to account for the three-level structure of our data (level 1-occupant, level 2-building, level 3-country). The ordered logistic regression analysis was applied using building and country as random effects and the covariates as fixed effects. Four step-by-step models were applied. The first was an empty model without any variable and with building and country variance only. In the second model, individual level variables were imported. The final version of the second model included variables, with $p$-value below 0.2 , such as gender, age (in four groups, $<35,35-45,46-55,>55$ ), effort reward ratio, experience of negative events, use of air fresheners at home, type of job (managerial, professional, clerical/secretarial, other), type of job contract (full-time, part-time), and job contract duration (permanent, fixed-term). In the third model, building characteristics were imported iteratively on the second model to identify significant relations with the perceived control. Variables with a $p$-value below 0.2 were selected to be used in the next model. In the fourth model, both individual and building level variables were imported. The results of the fixed effects were reported in Odds Ratios (OR) and 95\% Confidence Interval (CI). For the random effects, the explained variance is reported as well as the Proportional Change in Variance (PCV) between the null model and the final model with the variables.

iv. The potential relations between the occupants' perceived control and perceived comfort and reported health symptoms (PSI5) were examined by using the spearman correlation [45]. This study focused on the correlation between the various combined control scores (e.g., perceived control over temperature and ventilation) and the perceived occupants' comfort. Additionally, the dependent variable (overall comfort satisfaction) and the response-variables were expressed in values on an ordinal scale; hence, ordinal regression analysis was employed to determine the impact of the controlling parameters on overall comfort. In the regression model, the response-dependent variable was the overall comfort satisfaction and the predictor-independent variables were the satisfaction for each personal controlling parameter as evaluated by the occupants. The results are presented in the format of OR and its CI95\%. The ORs were used to rank the effect of the personal controlling parameters on overall comfort. $p$-values $<0.05$ were considered as statistically significant. The statistical package IBM SPSS Statistics [46] was used for the analysis. 


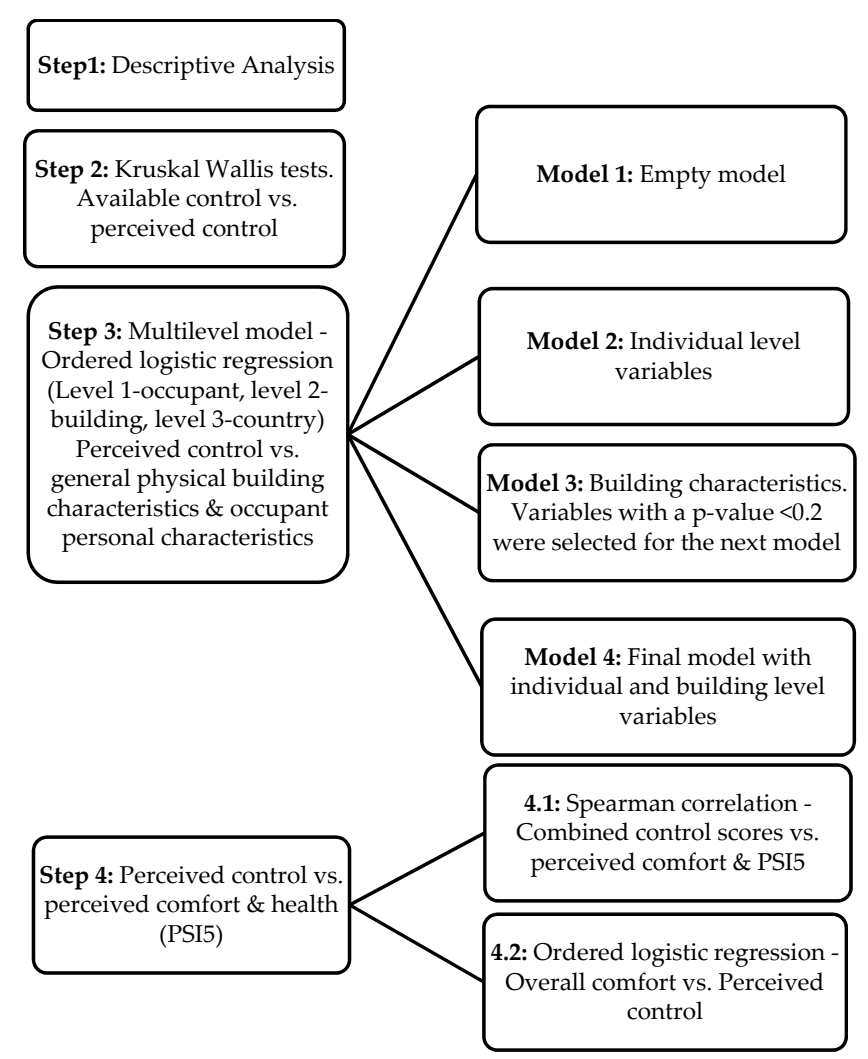

Figure 1. Schematic overview of the methodology used.

\section{Results}

\subsection{Characteristics of Perceived Personal Control}

The responses to the perceived controls (with a response rate above $99 \%$ for all control types) are presented in Figure 2. In general, noise, ventilation and temperature were perceived as poorly controlled. Regarding shading from the sun and lighting, the occupants reported the perceived control as moderate. A group of people (up to 35\%) declared "no control" can be observed for all control parameters. For temperature and ventilation control, the rest of the occupants are equally distributed in the five levels of control degree. Very few occupants seem to be able to control the noise level at their workstation, where answers follow a descending rate (full control below 5\%). On the contrary, regarding lighting and shading from the sun, after the distinctive "no control" group, the occupants' answers exhibited an ascending rate, indicating that they feel more able to control the light conditions (full control up to $20 \%$ ).

Figure 3 presents the percentages of the office occupants who have no or low perceived control (values $<4)$ on their indoor working environment. The majority $(63 \%)$ has no or low control on noise. Half of them declared no or low control on ventilation (53\%) and temperature (47\%). Almost one-third of them remarked that they do not have satisfactory levels of control for lighting and shading from sun conditions.

In Figure 4, the responses are presented based on the occupancy per room. Responses were categorized into five groups. In the first group, which is characterized by personal office rooms, occupants seem to have higher levels of control, except for ventilation. It is interesting to note that as the occupancy increases, the degree of personal control becomes lower. Offices with many occupants $(30+)$, probably open space offices, show the lowest degrees of personal control for all parameters. Furthermore, in all groups, the occupants characterized noise control as the worst parameter, while lighting and shading from the sun control gathered higher degrees of control. 


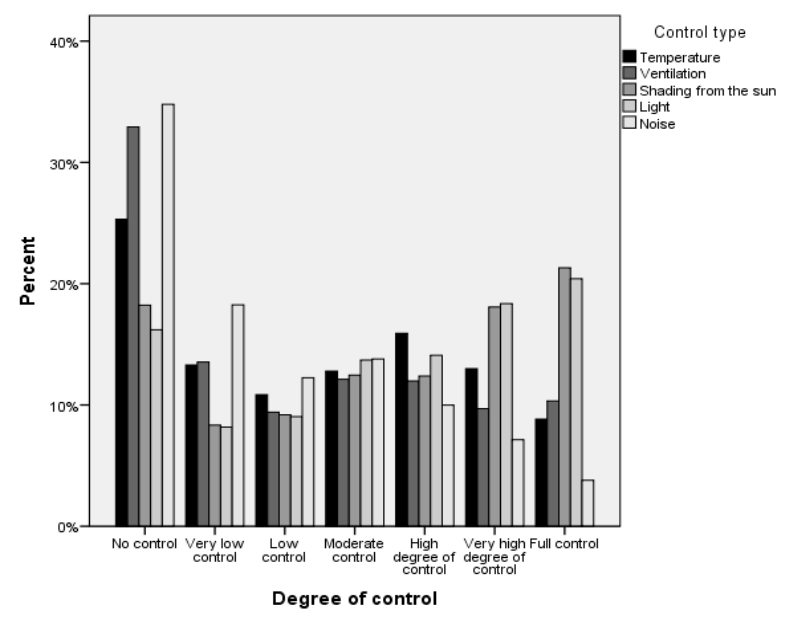

Figure 2. Percentage of occupants based on self-reported degree of control $(n=7441)$.

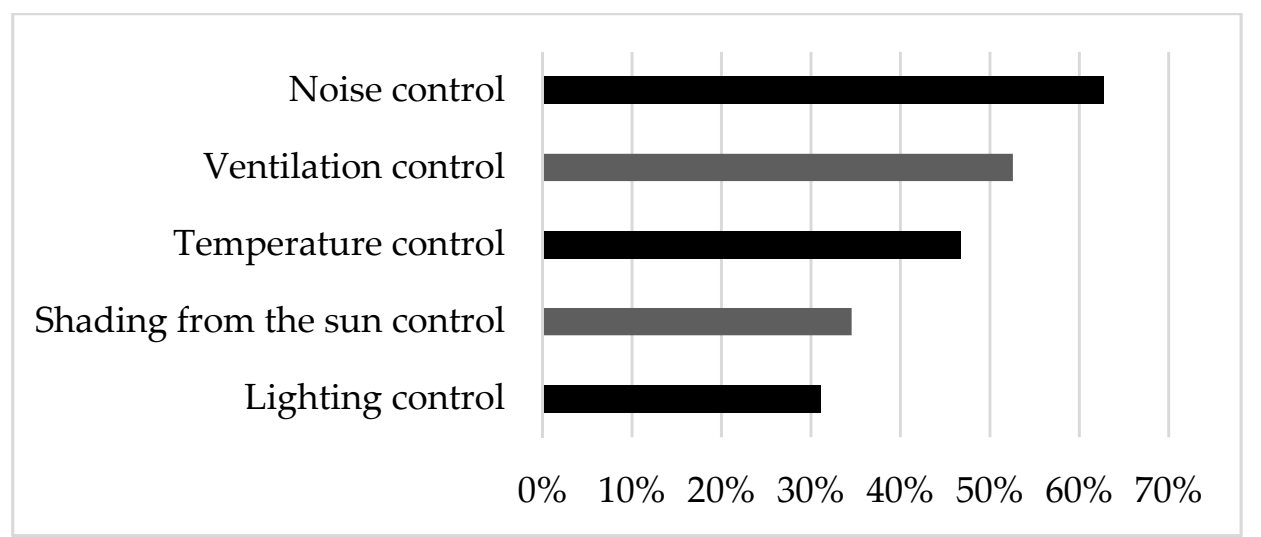

Figure 3. Percentage of occupants who reported no or low control.

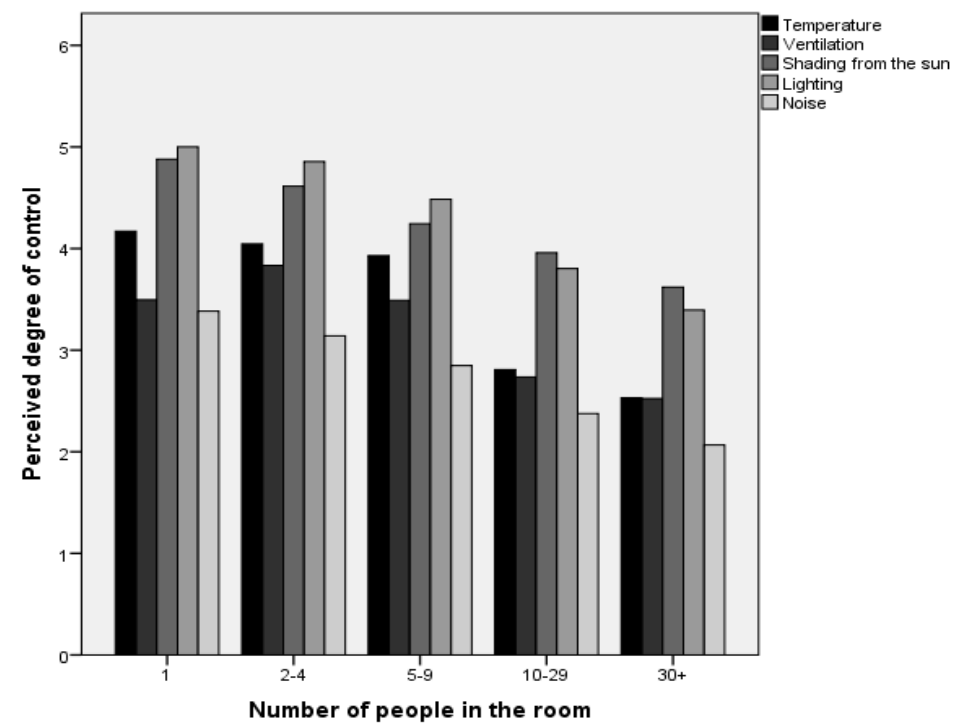

Figure 4. Mean degree of perceived control according to room occupancy ( $1=$ no control, $7=$ full control).

The satisfaction comfort towards IEQ parameters was also examined, with regard to their respective control options. The perceived satisfaction parameters were categorized in three levels of perceived control: no control (1), low control (2-3), high control $(\geq 4)$ and are presented in Figure 5. For each IEQ parameter, the related personal control option was selected, e.g., for parameters about temperature satisfaction, temperature control was selected; for indoor air quality parameters, ventilation control 
was selected, etc. Occupants with high degrees of personal control over their working environment reported higher levels of satisfaction on average. In all cases, occupants with high perceived control reported higher satisfaction levels. Occupants without personal control evaluated satisfaction of the IEQ with lower levels. Only in some cases, 'none' and 'low personal' control options are reversed, e.g., in the case of satisfaction with odor and reflection.

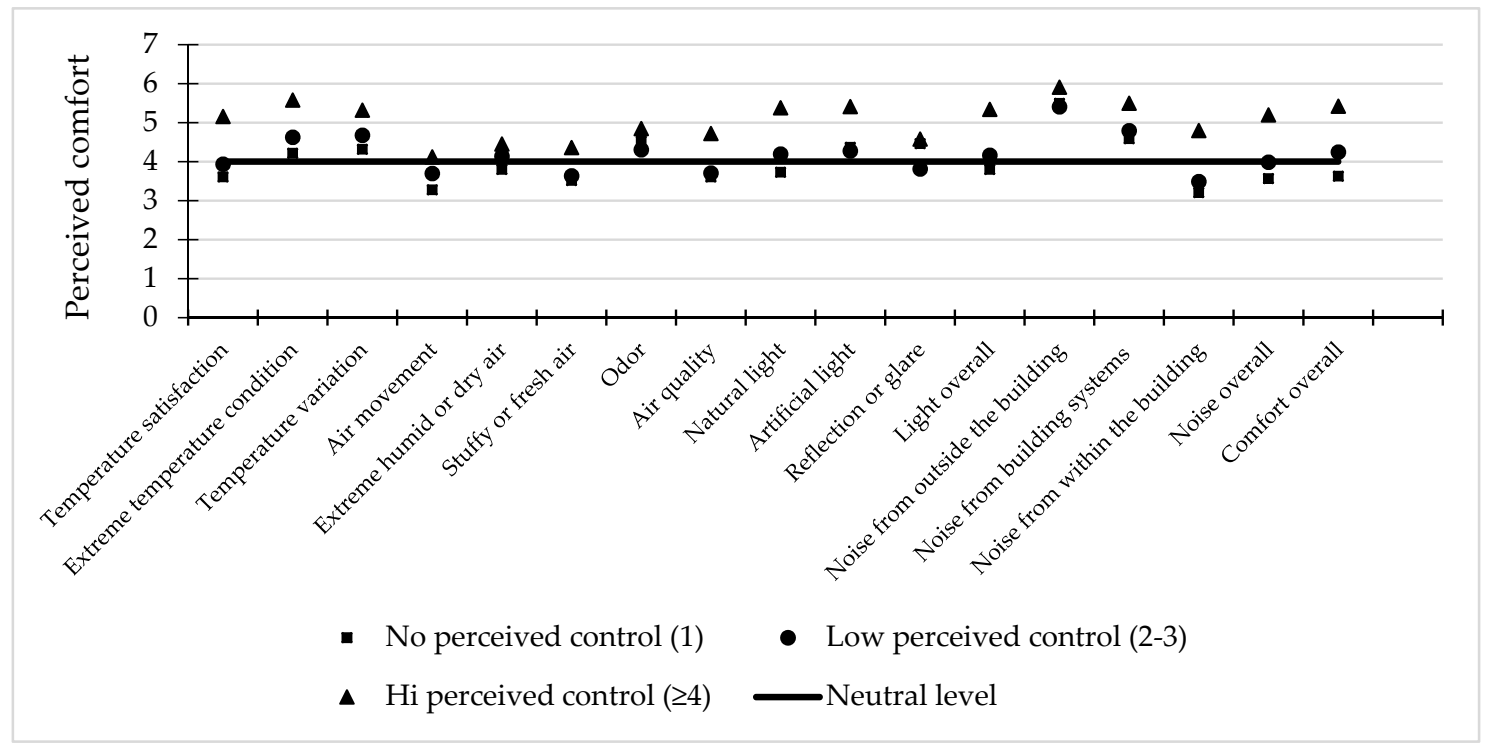

Figure 5. Perceived comfort towards indoor environment quality according to three levels of perceived control.

Figure 6 shows the degree of personal control vs. self-reported productivity at the workstation $(n=7289)$ and in other places in the building $(n=7154)$. In both cases, occupants with higher levels of personal control reported higher levels of productivity (Kruskal Wallis: $p<0.001$ ). Regarding the workstations, a small increase in the low control area results in a clear increase in productivity.
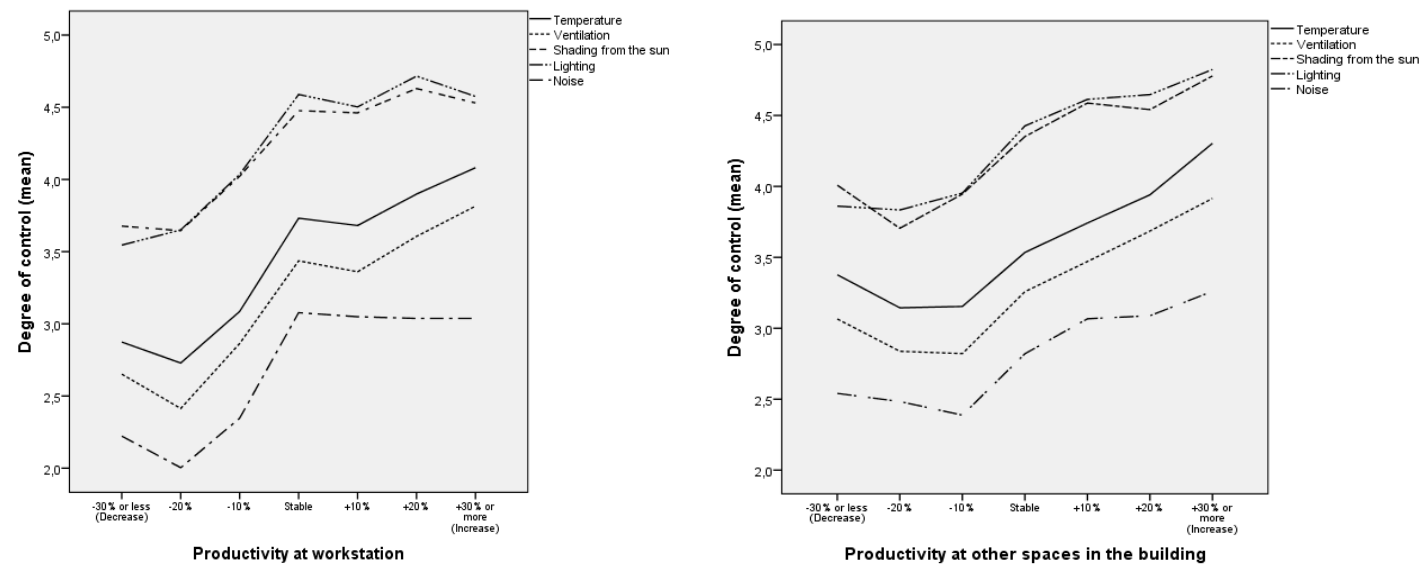

Figure 6. Self-reported productivity vs. degree of control.

\subsection{Relationship between Perceived Control and Available Control}

The statistically significant $(p<0.05)$ correlations between the available control and perceived control are presented in Figures 7-11.

Regarding the availability of operable windows (Figures 7-10), the scores of perceived control over temperature, ventilation, light and noise differ significantly $(p<0.001, p<0.001, p=0.001, p<0.001$, respectively) among buildings with operable windows, some operable windows, operable windows that people are not allowed to open, and no operable windows. The mean occupants' score over 
temperature in buildings with operable windows was 1.3 points higher than in buildings without operable windows $(p<0.001)$. The corresponding difference in the mean score for ventilation, light and noise was $2(p<0.001), 1(p<0.001)$ and $0.8(p=0.001)$, respectively.

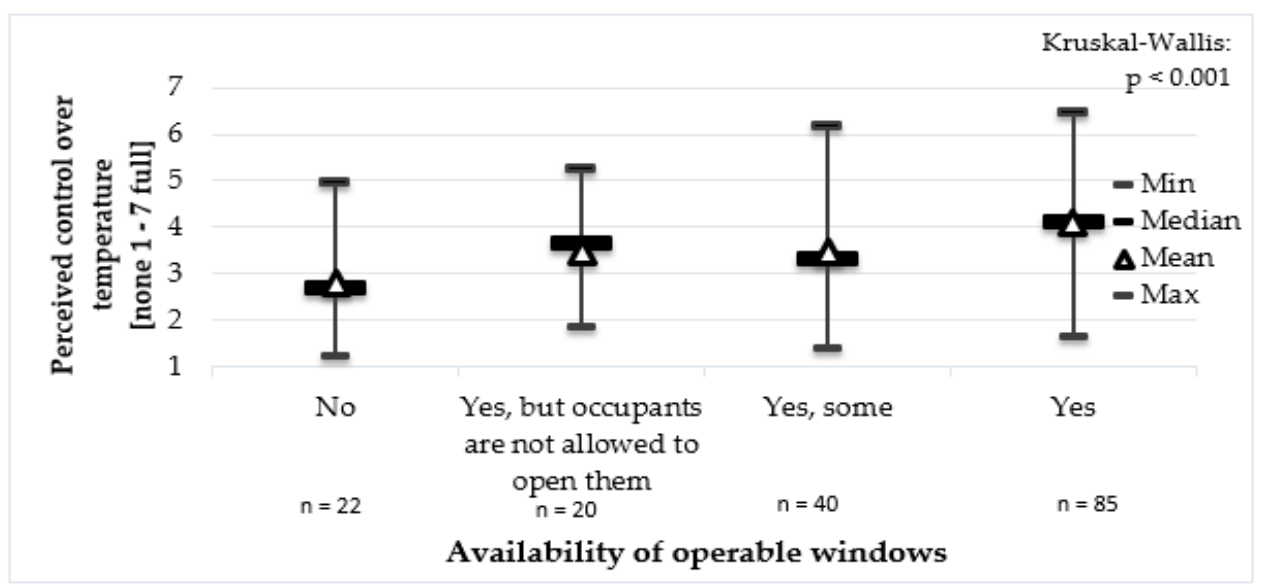

Figure 7. Perceived control over temperature vs. availability of operable windows ( $n$ is the number of office buildings).

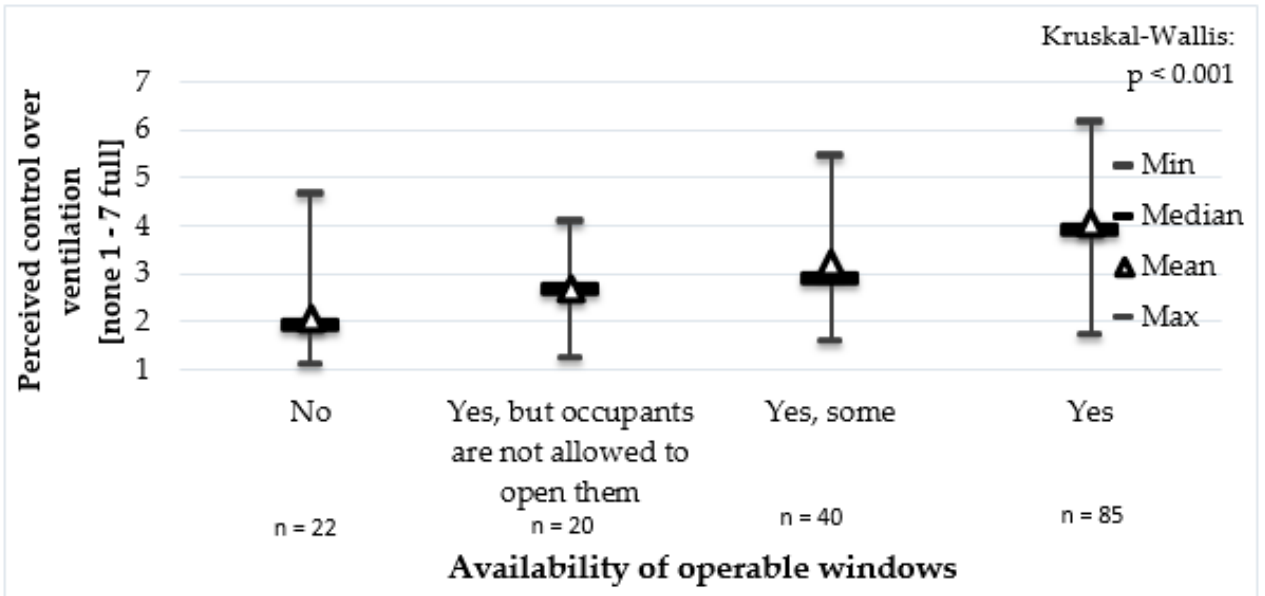

Figure 8. Perceived control over ventilation vs. availability of operable windows ( $n$ is the number of office buildings).

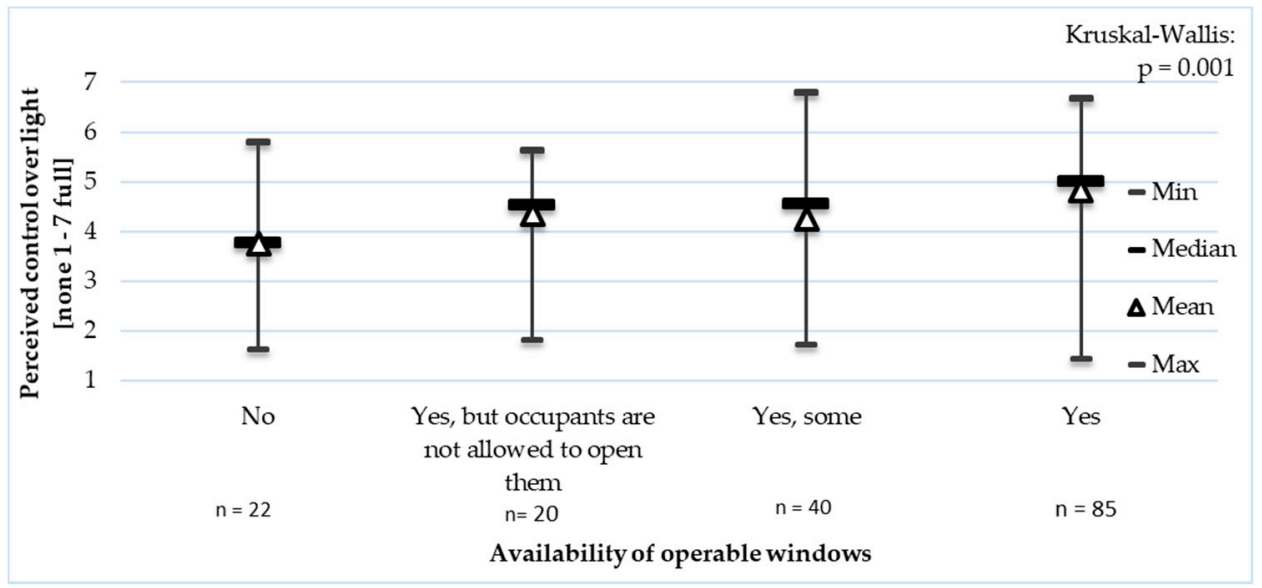

Figure 9. Perceived control over light vs. availability of operable windows ( $n$ is the number of office buildings). 


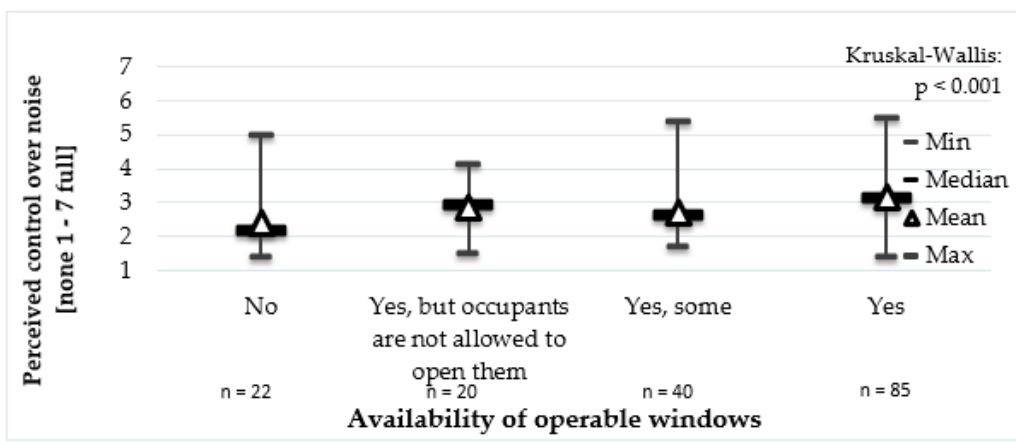

Figure 10. Perceived control over noise vs. availability of operable windows ( $n$ is the number of office buildings).

With regard to the presence of solar shading devices, the buildings were grouped into three categories based on the solar devices set up: internal, external, none (Figure 11). Perceived control over temperature varied significantly through the different types of the solar devices $(p=0.028)$. The highest score of perceived control over temperature was in buildings with no solar devices. This might be explained by the fact that the design of these office buildings provides adequate control over temperature without the use of solar shading devices; the multilevel regression analysis in the next step provides additional insights. No significant differences were observed between perceived control over shading and lighting in relation to the types of solar shading devices ( $p=0.635$ and $p=0.255$, respectively, Table 3).

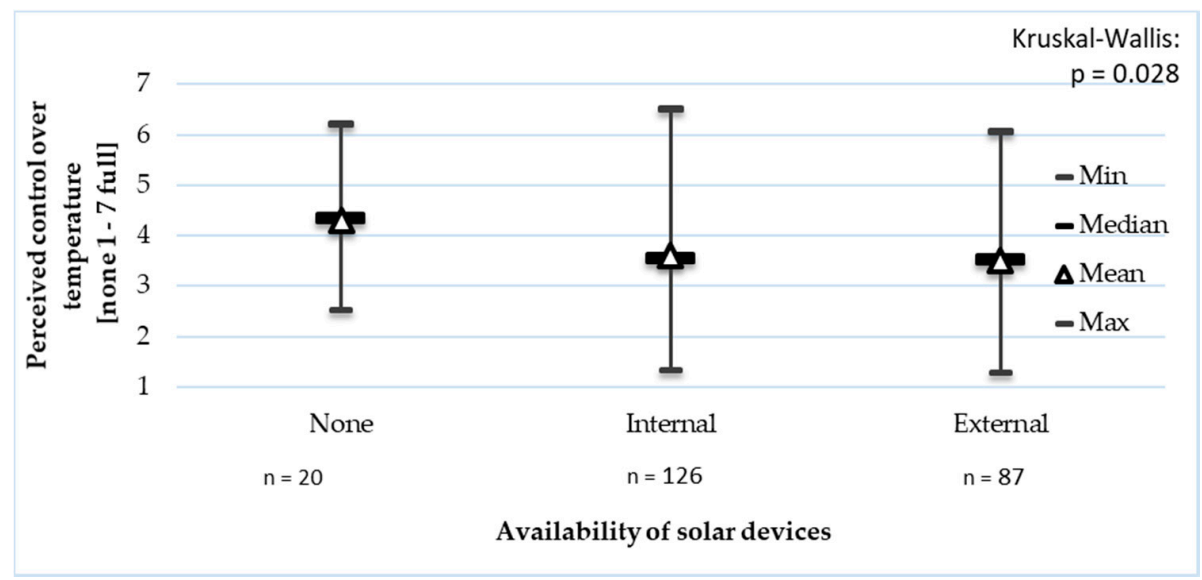

Figure 11. Perceived control over temperature vs. availability of solar shading devices $(n$ is the number of office buildings).

Table 3 presents the remaining outcomes of the statistical tests performed between the available control and occupants' perceived control. Regarding temperature control, the analysis showed no significant differences $(p=0.166)$ between the perceived control over temperature and the various types of temperature controls (e.g., manual radiator valve and central sensor). The different types of operable windows did not affect the perceived control of the shading from the sun $(p=0.100)$. Subsequently, the type of control on the solar shading devices (fixed, individual, central control, automatic) was examined (Table 3). Unlike the various types of solar devices, analysis of the available different control types of the shading devices showed that there are no significant differences among the scores of the perceived control over shading, lighting and temperature $(p=0.147, p=0.710$ and $p=0.755$, respectively). As far as the available controls of lights are concerned, no significant difference was found for perceived control over lighting $(p=0.328)$. Finally, the several types of mechanical ventilation control were examined. The occupants' perceived control over ventilation and temperature did not significantly differ ( $p=0.105$ and $p=0.768$, respectively) from the available control types. 
Table 3. Available control at building level and occupants' perceived control (from $1=$ no control at all to $7=$ full control) with $p>0.05$.

\begin{tabular}{|c|c|c|c|c|}
\hline & $\begin{array}{l}\text { Perceived Control } \\
\text { over Temperature }\end{array}$ & $\begin{array}{c}\text { Perceived Control } \\
\text { over Shading }\end{array}$ & $\begin{array}{l}\text { Perceived Control } \\
\text { over Light }\end{array}$ & $\begin{array}{c}\text { Perceived Control } \\
\text { over Ventilation }\end{array}$ \\
\hline \multicolumn{5}{|l|}{ Type of Available Temperature Controls } \\
\hline Manual radiator valve & 3.38 & & & \\
\hline Local thermostat at radiator/heating unit & 3.96 & & & \\
\hline Local thermostat (e.g., on wall) & 3.53 & & & \\
\hline Central sensor & 3.52 & & & \\
\hline Facade sensor(s)-i.e., outside temperature & 4.12 & & & \\
\hline Zone sensor(s) & 4.03 & & & \\
\hline Manual control in room(s) & 3.70 & & & \\
\hline$p$-value (Kruskal-Wallis test) & 0.166 & & & \\
\hline \multicolumn{5}{|l|}{ Availability of shading devices } \\
\hline None & & 4.09 & 4.69 & \\
\hline Internal & & 4.43 & 4.43 & \\
\hline External & & 4.22 & 4.44 & \\
\hline$p$-value (Kruskal-Wallis test) & & 0.635 & 0.255 & \\
\hline \multicolumn{5}{|l|}{ Type of control of the available solar shading devices } \\
\hline No control (fixed) & 3.45 & 3.90 & 4.53 & \\
\hline Individual & 3.60 & 4.43 & 4.43 & \\
\hline Central down, individual up & 3.25 & 4.46 & 3.76 & \\
\hline Automatic & 3.77 & 4.18 & 4.61 & \\
\hline$p$-value (Kruskal-Wallis test) & 0.755 & 0.147 & 0.710 & \\
\hline \multicolumn{5}{|l|}{ Type of operable windows } \\
\hline Yes & & 4.42 & & \\
\hline Yes, some & & 4.15 & & \\
\hline Yes, but occupants are not allowed to open them & & 4.81 & & \\
\hline No & & 4.11 & & \\
\hline$p$-value (Kruskal-Wallis test) & & 0.100 & & \\
\hline \multicolumn{5}{|l|}{ Type of available light controls } \\
\hline Manual & & & 4.52 & \\
\hline Demand control: Occupants (motion sensors) & & & 4.42 & \\
\hline Demand control: Daylight (photocells) & & & 4.26 & \\
\hline Automatic with manual end control (building/floor/zone) & & & 4.91 & \\
\hline Automatic by time (buildings/floor/zone) & & & 4.54 & \\
\hline$p$-value (Kruskal-Wallis test) & & & 0.328 & \\
\hline \multicolumn{5}{|l|}{ Type of available mechanical ventilation controls } \\
\hline Central-Manual (on/off) & 3.81 & & & 3.33 \\
\hline Central-Clock & 3.62 & & & 3.23 \\
\hline Central-Demand control (temperature, $\mathrm{CO}_{2}$, other pollutant, relative humidity) & 3.58 & & & 3.27 \\
\hline Local-Manual (on/off) & 4.11 & & & 4.27 \\
\hline Local一Clock & 3.74 & & & 3.78 \\
\hline Local-Demand control (temperature, $\mathrm{CO}_{2}$, other pollutant, relative humidity) & 4.42 & & & 3.73 \\
\hline$p$-value (Kruskal-Wallis test) & 0.768 & & & 0.105 \\
\hline
\end{tabular}




\subsection{Combined Perceived Control Versus Building Characteristics}

The variances of country and building level according to Model 1 (the null model) are 0.38 and 1.17, respectively. The respective variances in Model 2, which includes the individual variables (gender, age groups, effort reward ratio, experience of negative events, use of air fresheners at home, type of job, type of job's contract, job's contract duration), were 0.52 and 0.94 . The relations between the building characteristics, which were added in the model iteratively, and the combined perceived control with $p$-values $<0.2$ are presented in Table 4 (Model 3). The strongest associations with a $p$-value $<0.001$ were found for the building's location (suburban area), the maximum number of occupants, the documented complaints procedure, the number of people in office, as well as for the office type and availability of opening windows. Significant associations with a $p$-value $<0.05$ were found for the number of adjacent facades with other buildings, glares from neighboring buildings, total floor area, pesticide treatment plan, smoking permission, use of portable air cleaner, floor of the workspace, partition in the offices, and noise source of occupants-distracting conversations and the location of air and exhaust devices.

Table 4. Relations between combined overall perceived control and building characteristics (Model 3).

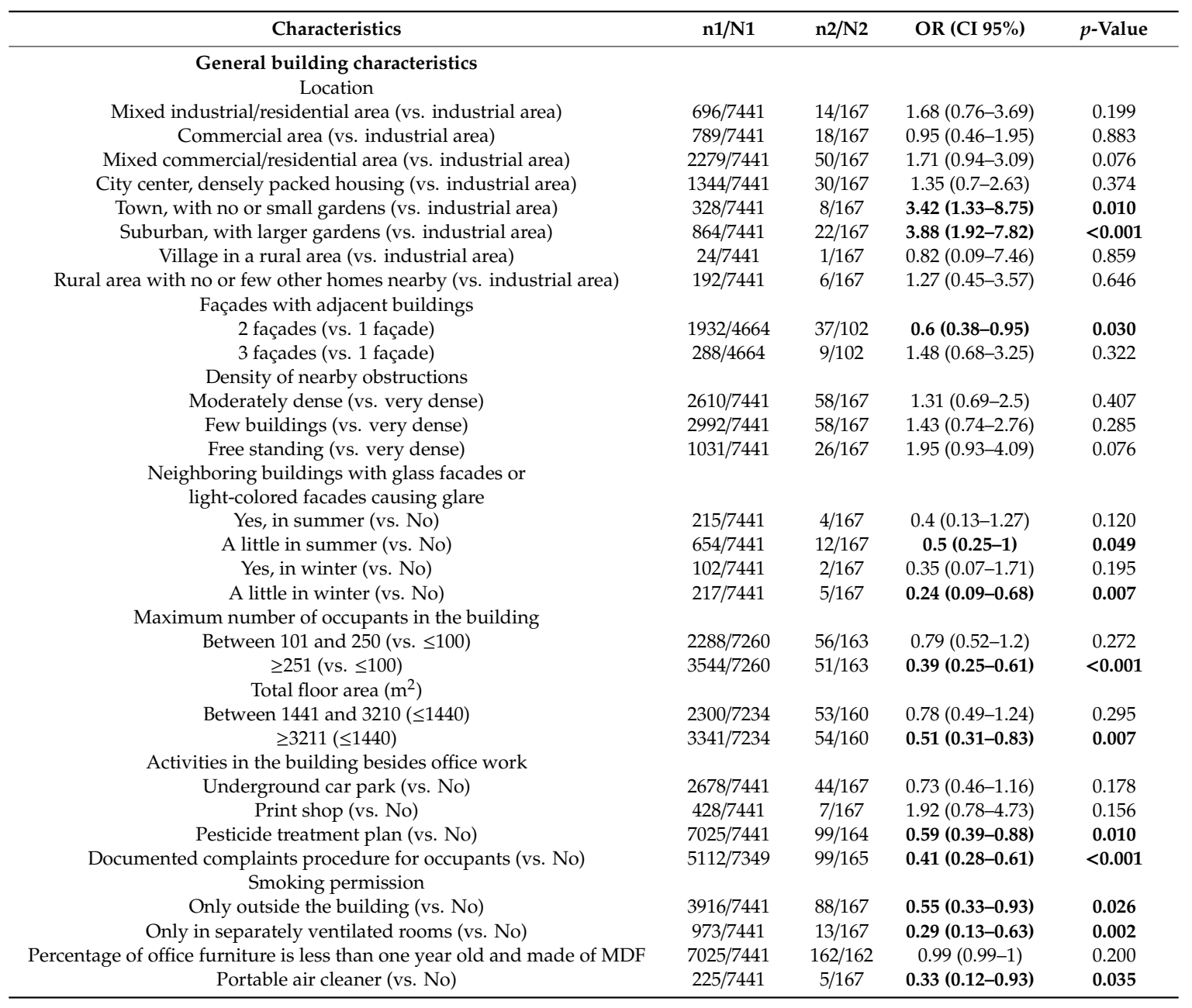


Table 4. Cont.

\begin{tabular}{|c|c|c|c|c|}
\hline Characteristics & n1/N1 & n2/N2 & OR (CI 95\%) & $p$-Value \\
\hline \multicolumn{5}{|l|}{ Office characteristics } \\
\hline Floor surface of the office & $7410 / 7441$ & $167 / 167$ & $1.05(1.02-1.09)$ & 0.001 \\
\hline \multicolumn{5}{|l|}{ Number of people in the office on average } \\
\hline $2-4$ (vs. $30+$ ) & $2134 / 7352$ & $152 / 167$ & $5.15(4.24-6.26)$ & $<0.001$ \\
\hline $5-9($ vs. $30+)$ & $1019 / 7352$ & $117 / 167$ & $2.62(2.15-3.21)$ & $<0.001$ \\
\hline $10-29$ (vs. 30+) & $1492 / 7352$ & $100 / 167$ & $1.48(1.25-1.76)$ & $<0.001$ \\
\hline Shared private office (vs. single person private office) & $2236 / 7417$ & $150 / 167$ & $0.56(0.48-0.65)$ & $<0.001$ \\
\hline Open space with partitions (vs. single person private office) & $991 / 7417$ & $115 / 167$ & $0.21(0.17-0.26)$ & $<0.001$ \\
\hline Open space without partitions (vs. single person private office) & $2602 / 7441$ & $139 / 167$ & $0.21(0.17-0.25)$ & $<0.001$ \\
\hline Other (vs. single person private office) & $90 / 7417$ & $60 / 167$ & $0.39(0.24-0.65)$ & $<0.001$ \\
\hline Partitions within the offices (vs. No) & $4112 / 7441$ & $91 / 167$ & $0.67(0.45-0.99)$ & 0.043 \\
\hline Noise source of occupants-distracting conversations (vs. No) & $2653 / 7441$ & $64 / 167$ & $0.66(0.45-0.98)$ & 0.040 \\
\hline In a separate printing room (vs. on the corridor) & $2501 / 7441$ & $47 / 167$ & $0.64(0.39-1.05)$ & 0.075 \\
\hline \multicolumn{5}{|l|}{ Operable windows } \\
\hline Yes (vs. No) & $3724 / 7441$ & $85 / 163$ & $5.51(3.14-9.67)$ & $<0.001$ \\
\hline Yes, some (vs. No) & $1769 / 7441$ & $40 / 163$ & $3.08(1.72-5.53)$ & $<0.001$ \\
\hline Yes, but occupants are not allowed to open them (vs. No) & $913 / 7441$ & $20 / 163$ & $1.54(0.79-2.98)$ & 0.204 \\
\hline Location of air supply devices inside offices—ceiling (vs. No air supply) & $5783 / 7441$ & $123 / 167$ & $0.63(0.4-0.99)$ & 0.046 \\
\hline \multicolumn{5}{|l|}{ Location of air exhaust devices inside offices } \\
\hline High (vs. None) & $6189 / 7089$ & $128 / 154$ & $0.46(0.25-0.87)$ & 0.017 \\
\hline Low (vs. None) & $382 / 7089$ & $10 / 154$ & $0.63(0.24-1.63)$ & 0.339 \\
\hline
\end{tabular}

$p$-values in bold are significant at $5 \%$. Adjusted for gender, age groups, effort reward ratio, experience of negative events, use of air fresheners at home, type of job, type of job's contract, job's contract duration. Characteristics with a p value lower than 0.20 are presented. Level 1-Occupant level, Level 2-Building level, Level 3-Country level. OR: Odd Ratio, CI: Confidence interval 95\%, n1/N1: Occupants' answers/total number of occupants, n2/N2: building observations/total number of buildings.

All individual and building characteristics from Models 2 and 3 were imported to Model 4; the relevant results are presented in Table 5. The variance between buildings was equal to 0.14 in Model 4 . PCV shows that $88 \%$ of the initial variance in overall perceived control was explained by the included variables. Buildings with larger total floor areas were positively associated with perceived overall control (OR 1.99, 95\% CI: 1.22-3.25). The workspace floor was also positively associated with control perception (OR 1.06, 95\% CI: 1.02-1.10). The existence of any kind of operable windows (OR 3.64 up to 6.53) and private and semi-private offices had the highest impact on the perceived overall control (OR 1.58 up to 3.73). On the other hand, the building's location (OR $0.24,95 \%$ CI: $0.06-0.96$ ) and the buildings' number of adjacent facades (OR 0.65, 95\% CI: 0.44-0.97) with other buildings tended to negatively associate with the perceived control. Both high number of occupants in the building (OR $0.67,95 \%$ CI: $0.46-0.99$ ) and the type of office (OR from 0.23 to 0.36 ) had a significant negative effect on the perceived overall control. Indoor noise from distracting conversations was associated negatively with the perceived overall control (OR 0.69, 95\% CI: 0.49-0.97).

Concerning individual characteristics, in addition to gender (OR 1.21, 95\% CI: 1.06-1.38) and age group (OR $0.78,95 \%$ CI: 0.61-0.99), strong association with the overall perceived control was found for the ERI (OR 0.67, 95\% CI: 0.46-0.99) and the occupants' habit to use air fresheners at home (OR 1.26, 95\% CI: 1.11-1.44). 
Table 5. Associations between combined overall perceived control, building characteristics and individual characteristics (Model 4).

\begin{tabular}{|c|c|c|}
\hline Factors & OR (CI 95\%) & $p$-Value \\
\hline \multicolumn{3}{|l|}{ Individual characteristics/personal activities } \\
\hline Female (vs. Male) & $1.21(1.06-1.38)$ & 0.006 \\
\hline \multicolumn{3}{|l|}{ Age } \\
\hline$<35$ (vs. $55+$ ) & $0.89(0.69-1.14)$ & 0.345 \\
\hline $35-45$ (vs. $55+$ ) & $0.78(0.61-0.99)$ & 0.040 \\
\hline $46-55$ (vs. $55+$ ) & $0.95(0.74-1.23)$ & 0.720 \\
\hline Effort-reward ratio & $0.31(0.25-0.38)$ & $<0.001$ \\
\hline Experience of negative events (vs. No) & $0.94(0.83-1.07)$ & 0.367 \\
\hline \multicolumn{3}{|l|}{$\begin{array}{l}\text { Type of job } \\
\text { The }\end{array}$} \\
\hline Managerial (vs. Other) & $0.97(0.75-1.27)$ & 0.844 \\
\hline Professional (vs. Other) & $0.98(0.78-1.23)$ & 0.873 \\
\hline Clerical-secretarial (vs. Other) & $0.95(0.77-1.17)$ & 0.625 \\
\hline Type of job's contract-Full-time (vs. Part-time) & $1.12(0.89-1.41)$ & 0.344 \\
\hline Job's contract duration-Permanent (vs. Fixed-term) & $1.13(0.91-1.39)$ & 0.263 \\
\hline Air fresheners use in home (vs. No) & $1.26(1.11-1.44)$ & $<0.001$ \\
\hline \multicolumn{3}{|l|}{ Building characteristics } \\
\hline \multicolumn{3}{|l|}{ Location } \\
\hline Mixed industrial/residential area (vs. industrial area) & $0.64(0.31-1.29)$ & 0.208 \\
\hline Commercial area (vs. industrial area) & $1.59(0.83-3.07)$ & 0.164 \\
\hline Mixed commercial/residential area (vs. industrial area) & $1.05(0.61-1.83)$ & 0.849 \\
\hline City Centre, densely packed housing (vs. industrial area) & $1.15(0.62-2.1)$ & 0.660 \\
\hline Town, with no or small gardens (vs. industrial area) & $2.98(0.95-9.39)$ & 0.062 \\
\hline Suburban, with larger gardens (vs. industrial area) & $1.73(0.63-4.72)$ & 0.285 \\
\hline Village in a rural area (vs. industrial area) & $0.24(0.06-0.96)$ & 0.043 \\
\hline Rural area with no or few other homes nearby (vs. industrial area) & $1.02(0.24-4.45)$ & 0.974 \\
\hline \multicolumn{3}{|l|}{ Density of nearby obstructions } \\
\hline Moderately dense (vs. Very dense) & $1.11(0.63-1.95)$ & 0.729 \\
\hline Few buildings (vs. Very dense) & $1.14(0.65-2.02)$ & 0.648 \\
\hline Free standing (vs. Very dense) & $0.99(0.44-2.19)$ & 0.972 \\
\hline \multicolumn{3}{|l|}{ Maximum number of occupants in the building } \\
\hline Between 101 and 250 (vs. $\leq 100)$ & $0.67(0.46-0.99)$ & 0.045 \\
\hline$\geq 251$ (vs. $\leq 100)$ & $0.92(0.56-1.52)$ & 0.745 \\
\hline \multicolumn{3}{|l|}{ Total floor area } \\
\hline Between 1441 and $3210(\leq 1440)$ & $1.99(1.22-3.25)$ & 0.006 \\
\hline$\geq 3211(\leq 1440)$ & $1.44(0.81-2.57)$ & 0.217 \\
\hline \multicolumn{3}{|l|}{ Façades with adjacent buildings } \\
\hline 2 façades (vs. 1 façade) & $0.65(0.44-0.97)$ & 0.033 \\
\hline 3 façades (vs. 1 façade) & $1(0.51-1.95)$ & 0.992 \\
\hline \multicolumn{3}{|l|}{ Neighboring buildings with glass facades or light-colored facades causing glare } \\
\hline Yes, in Summer (vs. No) & $3.16(1.15-8.66)$ & 0.025 \\
\hline A little in Summer (vs. No) & $1.52(0.74-3.14)$ & 0.256 \\
\hline Yes, in Winter (vs. No) & $0.24(0.06-0.94)$ & 0.040 \\
\hline A little in Winter (vs. No) & $0.49(0.17-1.39)$ & 0.180 \\
\hline \multicolumn{3}{|l|}{ Operable windows } \\
\hline Yes (vs. No) & $4.81(2.85-8.14)$ & $<0.001$ \\
\hline Yes, some (vs. No) & $6.53(3.76-11.34)$ & $<0.001$ \\
\hline Yes, but occupants are not allowed to open them (vs. No) & $3.64(1.82-7.27)$ & $<0.001$ \\
\hline \multicolumn{3}{|l|}{ Activities in the building besides office work } \\
\hline Underground car park (vs. No) & $0.79(0.52-1.19)$ & 0.258 \\
\hline Print shop (vs. No) & $1.4(0.6-3.27)$ & 0.435 \\
\hline Portable air cleaner (vs. No) & $0.79(0.31-2)$ & 0.622 \\
\hline Pesticide treatment plan (vs. No) & $1.33(0.74-2.38)$ & 0.336 \\
\hline \multicolumn{3}{|l|}{ Smoking permission } \\
\hline Only outside the building (vs. No) & $0.82(0.46-1.46)$ & 0.492 \\
\hline Only in separately ventilated rooms(vs. No) & $0.66(0.32-1.36)$ & 0.260 \\
\hline Documented complaints procedure for occupants (vs. No) & $0.77(0.5-1.17)$ & 0.221 \\
\hline Percentage of office furniture is less than one year old and made of MDF & $1(0.99-1.01)$ & 0.800 \\
\hline
\end{tabular}


Table 5. Cont.

\begin{tabular}{|c|c|c|}
\hline Factors & OR (CI 95\%) & $p$-Value \\
\hline \multicolumn{3}{|l|}{ Office characteristics } \\
\hline Floor surface of the office & $1.06(1.02-1.1)$ & 0.002 \\
\hline \multicolumn{3}{|l|}{ Number of people in the office on average } \\
\hline Private (vs. $30+$ ) & $2.51(1.59-3.97)$ & $<0.001$ \\
\hline $2-4$ (vs. 30+) & $3.73(2.78-4.99)$ & $<0.001$ \\
\hline $5-9$ (vs. 30+) & $2.3(1.79-2.96)$ & $<0.001$ \\
\hline $10-29$ (vs. $30+)$ & $1.58(1.29-1.93)$ & $<0.001$ \\
\hline \multicolumn{3}{|l|}{ Type of office } \\
\hline Shared private office (vs. Single person private office) & $0.36(0.23-0.55)$ & $<0.001$ \\
\hline Open space with partitions (vs. Single person private office) & $0.23(0.14-0.36)$ & $<0.001$ \\
\hline Open space without partitions (vs. Single person private office) & $0.26(0.17-0.4)$ & $<0.001$ \\
\hline Other (vs. Single person private office) & $0.57(0.25-1.29)$ & 0.178 \\
\hline Partitions within the offices (vs. No) & $1.02(0.64-1.61)$ & 0.935 \\
\hline Noise source of Occupants-distracting conversations (vs. No) & $0.69(0.49-0.97)$ & 0.034 \\
\hline \multicolumn{3}{|l|}{ PC or laptop monitor position } \\
\hline In front of windows (vs. Not) & $1.32(0.94-1.86)$ & 0.103 \\
\hline \multicolumn{3}{|l|}{ Printer/copy machines location } \\
\hline In the offices (vs. on the corridor) & $0.99(0.63-1.55)$ & 0.956 \\
\hline In a separate printing room (vs. on the corridor) & $1.23(0.76-1.99)$ & 0.396 \\
\hline Location of air supply devices inside offices-ceiling (vs. No air supply) & $0.81(0.51-1.28)$ & 0.365 \\
\hline \multicolumn{3}{|l|}{ Location of air exhaust devices inside offices } \\
\hline High (vs. None) & $1.43(0.61-3.34)$ & 0.408 \\
\hline Low (vs. None) & $0.93(0.37-2.35)$ & 0.879 \\
\hline County level $\sigma 2 / \mathrm{PCV}(\%)$ & $0.42 / 10$ & \\
\hline Building level $\sigma 2 / \mathrm{PCV}(\%)$ & $0.14 / 88$ & \\
\hline
\end{tabular}

\subsection{Impact of Perceived Control on Perceived Comfort and Health}

\subsubsection{Combined Perceived Control vs. Perceived Comfort and Health—Bivariate Analysis}

The relationships between perceived control and perceived comfort are presented in Table 6 . Perceived overall comfort correlated significantly and positively with perceived control over all control parameters. When the scores of the perceived control were combined, the correlation with the overall comfort increased, reaching the highest value of $r=0.465$. The combined correlation values are stronger than the correlations between the single perceived control parameters. The strongest correlation for perceived overall temperature was indicated with control over temperature $(r=0.420)$ and not with the combined controls. The satisfaction with extreme hot or cold temperature conditions seems to have the strongest correlation only with the control over temperature $(r=0.281)$, while the combined perceived controls show equal effect. On the other hand, temperature variation was found to be more related to the combined control over temperature and shading from the sun controls $(r=0.209)$. Perceived air quality about dry or humid air and odor did not show strong correlations, either with single or with combined perceived control parameters, indicating that these parameters were more difficult to be controlled by the occupants. However, perceived overall air quality satisfaction and perceived satisfaction with fresh air were found to be more correlated with the combined control perception over temperature, ventilation and shading from the sun ( $r=0.380$ and 0.320 , respectively).

Perceived comfort regarding natural light correlated positively with perceived control over shading from the sun and over light $(r=0.370)$. Moreover, artificial light perception showed correlation with the perceived control over light $(r=0.377)$. This means that occupants with higher degrees of shading and lighting controls feel more satisfied with the light levels in their offices. Perceived satisfaction with glare did not show strong correlation. In general, combined controls do not significantly affect light satisfaction. 
Table 6. Correlations between combined perceived control and perceived comfort and health.

\begin{tabular}{|c|c|c|c|c|}
\hline & $\begin{array}{l}\text { Perceived Control over } \\
\text { Temperature and } \\
\text { Ventilation Combined } \\
\text { [2: None at all-14: } \\
\text { Full Control] }\end{array}$ & $\begin{array}{l}\text { Perceived Control over } \\
\text { Temperature and Shading } \\
\text { from the Sun Combined } \\
\text { [2: None at all-14: } \\
\text { Full Control] }\end{array}$ & $\begin{array}{c}\text { Perceived Control over } \\
\text { Temperature, Ventilation and } \\
\text { Shading from the Sun } \\
\text { Combined [3: None at all-21: } \\
\text { Full Control] }\end{array}$ & $\begin{array}{l}\text { Perceived Control over } \\
\text { Temperature, Ventilation, } \\
\text { Shading from the Sun, Light } \\
\text { and Noise Combined [5: None } \\
\text { at all-35: Full Control] }\end{array}$ \\
\hline Overall comfort [1: Unsatisfactory-7: Satisfactory] & $\begin{array}{l}0.367 \\
<0.001\end{array}$ & $\begin{array}{l}0.415 \\
<0.001\end{array}$ & $\begin{array}{l}0.415 \\
<0.001\end{array}$ & $\begin{array}{c}0.465 \\
<0.001\end{array}$ \\
\hline Temperature [1: Too hot/cold- 7: Satisfactory] & $\begin{array}{c}0.258 \\
<0.001\end{array}$ & $\begin{array}{c}0.257 \\
<0.001 \\
\end{array}$ & $\begin{array}{c}0.255 \\
<0.001 \\
\end{array}$ & $\begin{array}{c}0.245 \\
<0.001 \\
\end{array}$ \\
\hline Temperature [1: Varies too much/not enough variation-7: Satisfactory] & $\begin{array}{c}0.154 \\
<0.001\end{array}$ & $\begin{array}{c}0.209 \\
<0.001\end{array}$ & $\begin{array}{c}0.186 \\
<0.001\end{array}$ & $\begin{array}{c}0.188 \\
<0.001\end{array}$ \\
\hline Temperature [1: Unsatisfactory-7: Satisfactory] & $\begin{array}{c}0.403 \\
<0.001\end{array}$ & $\begin{array}{c}0.414 \\
<0.001\end{array}$ & $\begin{array}{c}0.416 \\
<0.001\end{array}$ & $\begin{array}{c}0.43 \\
<0.001\end{array}$ \\
\hline Air movement [1: Draughty/Still- 7: Satisfactory] Air movement & $\begin{array}{c}0.175 \\
<0.001\end{array}$ & $\begin{array}{c}0.164 \\
<0.001\end{array}$ & $\begin{array}{c}0.178 \\
<0.001\end{array}$ & $\begin{array}{c}0.182 \\
<0.001\end{array}$ \\
\hline Air quality [1: Dry/humid-7: Satisfactory] & $\begin{array}{c}0.143 \\
<0.001\end{array}$ & $\begin{array}{c}0.142 \\
<0.001\end{array}$ & $\begin{array}{c}0.147 \\
<0.001\end{array}$ & $\begin{array}{c}0.162 \\
<0.001\end{array}$ \\
\hline Air quality [1: Stuffy- 7: Fresh] & $\begin{array}{c}0.287 \\
<0.001\end{array}$ & $\begin{array}{c}0.312 \\
<0.001\end{array}$ & $\begin{array}{c}0.322 \\
<0.001\end{array}$ & $\begin{array}{c}0.342 \\
<0.001\end{array}$ \\
\hline Air quality [1: Smelly-7: Odorless] & $\begin{array}{c}0.129 \\
<0.001 \\
\end{array}$ & $\begin{array}{c}0.183 \\
<0.001 \\
\end{array}$ & $\begin{array}{c}0.17 \\
<0.001 \\
\end{array}$ & $\begin{array}{c}0.195 \\
<0.001\end{array}$ \\
\hline Air quality [1: Unsatisfactory-7: Satisfactory] & $\begin{array}{c}0.35 \\
<0.001 \\
\end{array}$ & $\begin{array}{c}0.363 \\
<0.001\end{array}$ & $\begin{array}{c}0.38 \\
<0.001\end{array}$ & $\begin{array}{c}0.405 \\
<0.001\end{array}$ \\
\hline Natural light [1: Unsatisfactory-7: Satisfactory] & $\begin{array}{c}0.247 \\
<0.001\end{array}$ & $\begin{array}{c}0.356 \\
<0.001\end{array}$ & $\begin{array}{c}0.342 \\
<0.001\end{array}$ & $\begin{array}{c}0.361 \\
<0.001\end{array}$ \\
\hline Artificial light [1: Unsatisfactory-7: Satisfactory] & $\begin{array}{c}0.245 \\
<0.001\end{array}$ & $\begin{array}{c}0.281 \\
<0.001\end{array}$ & $\begin{array}{c}0.284 \\
<0.001\end{array}$ & $\begin{array}{c}0.331 \\
<0.001\end{array}$ \\
\hline Reflection or glare [1: Glarel-7: No glare] & $\begin{array}{c}0.123 \\
<0.001\end{array}$ & $\begin{array}{c}0.145 \\
<0.001\end{array}$ & $\begin{array}{c}0.142 \\
<0.001\end{array}$ & $\begin{array}{c}0.166 \\
<0.001\end{array}$ \\
\hline Light overall [1: Unsatisfactory-7: Satisfactory] & $\begin{array}{c}0.295 \\
<0.001\end{array}$ & $\begin{array}{c}0.364 \\
<0.001\end{array}$ & $\begin{array}{c}0.361 \\
<0.001\end{array}$ & $\begin{array}{c}0.401 \\
<0.001\end{array}$ \\
\hline Noise from outside the building [1: Unsatisfactory-7: Satisfactory] & $\begin{array}{c}-0.004 \\
0.707\end{array}$ & $\begin{array}{c}0.077 \\
<0.001\end{array}$ & $\begin{array}{l}0.048 \\
<0.001\end{array}$ & $\begin{array}{c}0.077 \\
<0.001\end{array}$ \\
\hline $\begin{array}{l}\text { Noise from building systems (e.g., heating, plumbing, ventilation, air } \\
\text { conditioning) [1: Unsatisfactory-7: Satisfactory] }\end{array}$ & $\begin{array}{c}0.172 \\
<0.001\end{array}$ & $\begin{array}{c}0.191 \\
<0.001\end{array}$ & $\begin{array}{c}0.198 \\
<0.001\end{array}$ & $\begin{array}{c}0.226 \\
<0.001\end{array}$ \\
\hline $\begin{array}{l}\text { Noise from within the building other than from building systems (e.g., phone } \\
\text { calls, colleagues chatting, photocopiers, etc.) [1: Unsatisfactory-7: Satisfactory] }\end{array}$ & $\begin{array}{c}0.28 \\
<0.001\end{array}$ & $\begin{array}{c}0.302 \\
<0.001\end{array}$ & $\begin{array}{c}0.304 \\
<0.001\end{array}$ & $\begin{array}{c}0.367 \\
<0.001\end{array}$ \\
\hline
\end{tabular}


Table 6. Cont

\begin{tabular}{|c|c|c|c|c|}
\hline & $\begin{array}{l}\text { Perceived Control over } \\
\text { Temperature and } \\
\text { Ventilation Combined } \\
\text { [2: None at all-14: } \\
\text { Full Control] }\end{array}$ & $\begin{array}{l}\text { Perceived Control over } \\
\text { Temperature and Shading } \\
\text { from the Sun Combined } \\
\text { [2: None at all-14: } \\
\text { Full Control] }\end{array}$ & $\begin{array}{l}\text { Perceived Control over } \\
\text { Temperature, Ventilation and } \\
\text { Shading from the Sun } \\
\text { Combined [3: None at all-21: } \\
\text { Full Control] }\end{array}$ & $\begin{array}{l}\text { Perceived Control over } \\
\text { Temperature, Ventilation, } \\
\text { Shading from the Sun, Light } \\
\text { and Noise Combined [5: None } \\
\text { at all-35: Full Control] }\end{array}$ \\
\hline Noise overall [1: Unsatisfactory-7: Satisfactory] & $\begin{array}{c}0.286 \\
<0.001\end{array}$ & $\begin{array}{l}0.322 \\
0.000\end{array}$ & $\begin{array}{l}0.321 \\
0.000\end{array}$ & $\begin{array}{l}0.389 \\
0.000\end{array}$ \\
\hline Vibration [1: Unsatisfactory-7: Satisfactory] & $\begin{array}{c}0.108 \\
<0.001\end{array}$ & $\begin{array}{c}0.177 \\
<0.001\end{array}$ & $\begin{array}{c}0.16 \\
<0.001\end{array}$ & $\begin{array}{c}0.193 \\
<0.001\end{array}$ \\
\hline Amount of privacy [1: Unsatisfactory-7: Satisfactory] & $\begin{array}{c}0.333 \\
<0.001\end{array}$ & $\begin{array}{c}0.385 \\
<0.001\end{array}$ & $\begin{array}{c}0.379 \\
<0.001\end{array}$ & $\begin{array}{c}0.433 \\
<0.001\end{array}$ \\
\hline Layout [1: Do not like at all-7: Like very much] & $\begin{array}{c}0.31 \\
<0.001\end{array}$ & $\begin{array}{c}0.367 \\
<0.001\end{array}$ & $\begin{array}{c}0.361 \\
<0.001\end{array}$ & $\begin{array}{c}0.403 \\
<0.001\end{array}$ \\
\hline Decoration [1: Do not like at all-7: Like very much] & $\begin{array}{c}0.22 \\
<0.001 \\
\end{array}$ & $\begin{array}{c}0.295 \\
<0.001\end{array}$ & $\begin{array}{c}0.278 \\
<0.001\end{array}$ & $\begin{array}{c}0.315 \\
<0.001\end{array}$ \\
\hline View from the windows [1: Do not like at all-7: Like very much] & $\begin{array}{c}0.147 \\
<0.001\end{array}$ & $\begin{array}{c}0.256 \\
<0.001\end{array}$ & $\begin{array}{c}0.233 \\
<0.001\end{array}$ & $\begin{array}{c}0.246 \\
<0.001\end{array}$ \\
\hline PSI5 & $\begin{array}{l}-0.249 \\
<0.001\end{array}$ & $\begin{array}{l}-0.251 \\
<0.001\end{array}$ & $\begin{array}{l}-0.263 \\
<0.001\end{array}$ & $\begin{array}{l}-0.289 \\
<0.001\end{array}$ \\
\hline
\end{tabular}

Rho and $p$-value of Spearman correlation. Significant at $5 \%$ is in bold. 
Perceived comfort over outdoor noise seems to have low correlation with perceived controls. The occupants were not able to control the noise levels coming from outside probably due to inefficient available control types. Noise from building systems and noise within the building correlated positively with perceived control over noise $(r=0.205$ and 0.377$)$. Moreover, the occupants were more satisfied with the noise from building systems when they had higher degree of all combined controls $(r=0.226)$. The highest correlation was observed $(r=0.408)$ between the overall noise satisfaction and perceived noise control. This indicates that the occupants are more comfortable in buildings where they perceive high degree of control over noise.

The amount of privacy was found to have significant correlation with all control parameters, both single and combined, while the maximum correlation was recorded with all combined controls $(r=0.433)$. This implies that high degrees of personal control improve the privacy that the occupant needs. This positive relation was also observed for office layout and decoration perceived satisfaction with $r=0.403$ and 0.315 , respectively.

As far as perceived control and the presence of health symptoms assessed through the PSI5 are concerned, a significant negative correlation was found for all control parameters, both single and combined. The combined perceived control scores exhibited a stronger negative correlation with the PSI5.

\subsubsection{Perceived Control vs. Perceived Overall Comfort—Regression Analysis}

The relation between the overall comfort and five perceived control variables has been examined by applying the ordinal regression analysis. The results are presented in Table 7 . The maximum OR value (1.28) corresponded to the perceived control over noise. The results showed that if the perceived control over noise increases by one unit in the 1-7 point scale, there is a 1.28 time likelihood that the overall comfort will increase by one unit. Perceived noise control was the parameter with the lowest score according to the occupants' recordings, as shown in Table 2. The impact on the overall comfort of the control over noise, lighting, temperature and shading from the sun, was almost equivalent (ORs: 1.16, 1.14 and 1.12, respectively). Lastly, the perceived control over ventilation, despite the fact that it was ranked as the second worst parameter, had the lowest impact on overall comfort (OR 1.03, 95\% CI: $1.00-1.06)$.

Table 7. Relations between perceived control and perceived overall comfort.

\begin{tabular}{ccc}
\hline Parameters & OR CI (95\%) & $p$-Value \\
\hline Perceived control over noise & $\mathbf{1 . 2 8}(\mathbf{1 . 2 5 - 1 . 3 2 )}$ & $p<0.001$ \\
Perceived control over lighting & $\mathbf{1 . 1 6}(\mathbf{1 . 1 3 - 1 . 1 9 )}$ & $p<0.001$ \\
Perceived control over temperature & $\mathbf{1 . 1 4}(\mathbf{1 . 1 1 - 1 . 1 8 )}$ & $p<0.001$ \\
Perceived control over shade & $\mathbf{1 . 1 2 ( 1 . 1 0 - 1 . 1 5 )}$ & $p<0.001$ \\
Perceived control over ventilation & $\mathbf{1 . 0 3 ( 1 . 0 0 - 1 . 0 6 )}$ & $p<\mathbf{0 . 0 5}$ \\
\hline
\end{tabular}

Moreover, occupants were separated in two groups: those who had no or low control and those who had high control for the sum of the five control parameters. The results are presented in Table 8 . The ranking remains the same as in the previous case, but two remarks can be highlighted. First, in the "low control" group, occupants were less sensitive to controlling parameters, with lower OR values. In addition, the perceived control over ventilation was not significant $(p>0.05)$. Second, in the "high control" group, occupants were more sensitive to all controlling parameters with increased OR values. The perceived control over lighting showed an almost equal impact on overall comfort as the perceived control over noise. 
Table 8. Relations between perceived control in low and high control groups and perceived overall comfort.

\begin{tabular}{|c|c|c|c|c|c|}
\hline $\begin{array}{c}\text { Parameters- } \\
\text { Low Control Group }\end{array}$ & OR CI (95\%) & $p$-Value & $\begin{array}{c}\text { Parameters- } \\
\text { High Control Group }\end{array}$ & OR CI $(95 \%)$ & CI $(95 \%)$ \\
\hline $\begin{array}{l}\text { Perceived control } \\
\text { over noise }\end{array}$ & $1.21(1.15-1.27)$ & $p<0.001$ & $\begin{array}{l}\text { Perceived control } \\
\text { over noise }\end{array}$ & $1.37(1.32-1.43)$ & $p<0.001$ \\
\hline $\begin{array}{l}\text { Perceived control } \\
\text { over lighting }\end{array}$ & $1.14(1.11-1.17)$ & $p<0.001$ & $\begin{array}{l}\text { Perceived control } \\
\text { over lighting }\end{array}$ & $1.32(1.25-1.39)$ & $p<0.001$ \\
\hline $\begin{array}{l}\text { Perceived control } \\
\text { over temperature }\end{array}$ & $1.11(1.06-1.15)$ & $p<0.001$ & $\begin{array}{l}\text { Perceived control } \\
\text { over temperature }\end{array}$ & $1.26(1.20-1.31)$ & $p<0.001$ \\
\hline $\begin{array}{l}\text { Perceived control } \\
\text { over shade }\end{array}$ & $1.10(1.07-1.13)$ & $p<0.001$ & $\begin{array}{l}\text { Perceived control } \\
\text { over shade }\end{array}$ & $1.19(1.14-1.25)$ & $p<0.001$ \\
\hline $\begin{array}{l}\text { Perceived control } \\
\text { over ventilation }\end{array}$ & $0.99(0.95-1.04)$ & $p>0.05$ & $\begin{array}{l}\text { Perceived control } \\
\text { over ventilation }\end{array}$ & $1.08(1.04-1.12)$ & $p<0.001$ \\
\hline
\end{tabular}

\section{Discussion}

\subsection{Occupants' Personal Control}

The current study analyzed data from 7441 occupants in 167 European modern office buildings, sustaining and reinforcing findings from previous studies, revealing the importance of the perceived personal control over indoor environment parameters.

The overall occupants' comfort should be examined by investigating the role of every aspect of personal control. Paciuk [16] highlighted three aspects of personal control; (i) available control, (ii) exercised control; (iii) perceived control. Available control can be described by the degree and type of control made available by the environment. It can be defined by 'the degree of manipulation of thermostats and other manual controls as well as the existence of operable windows, blinds, sunshades, ventilation vanes, doors and HVAC system components'. Exercised control is defined by 'the relative frequency in which occupants engage in several types of thermal-related behaviors in order to obtain thermal comfort when needed'. The occupants' perceived control is being produced as the interaction of the different degrees of available (building controls) and exercised control (frequency of use). OFFICAIR database does not include information about the occupants' exercise control so in that study this aspect was not examined. The main idea is that personal control, both available and perceived, works as a moderator affecting the occupants' satisfaction on IEQ parameters and on the overall comfort.

Paciuk [16] examined the perceived control over temperature, ventilation, shading from the sun, lighting and noise. The results showed that occupants have moderate or low control on these parameters with a significant group of occupants, who declared that they had no access to the control of their environment. This was also remarked by Haghighat and Donnini [19], where almost $60 \%$ of the responders had no control access. Furthermore, around 30\% of the participants were very dissatisfied with the level of control. An interesting relationship between the perceived productivity in offices and perceived control has emerged, where higher productivity levels were recorded when occupants perceived higher degrees of personal control. Boardass et al. [18] also pointed out the issue of productivity versus personal control, concluding in the same finding.

In this analysis, only a limited number of available control types were found to be associated with the perceived control. Perceived control over temperature, ventilation, light and noise was found to be associated only with the presence of operable windows. The effect of operable windows in the indoor environment on occupants' comfort was also raised by Brager et al. [47]. The scores of perceived temperature control differ significantly with the different types of solar shading devices. However, after importing these available control types along with various general building characteristics in the multilevel model, only operable windows remained significant. Similar findings were also 
reported in another study [48] where opening windows were the most frequent behavior of controlling thermal conditions. The limited effect of the available control on the perceived control was pointed out in previous studies $[23,24]$, which found no association between available and perceived control. This could be explained by the fact that occupants could identify the available controls, but they were not allowed to use them or did not know how to set them up or the control types could not respond rapidly. The multilevel model, containing both individual and building characteristics (both general and available control types), showcased $88 \%$ variance in perceived control between buildings. A Building's location and the distance with adjacent facades from other neighboring buildings seem to be significant. The area and number of floors were also found to affect occupant control perception. The number of occupants inside the building showed strong effect, especially inside the office, as well as the type of office (private or open space with partitions). Gou et al. [49] remarked that the provision of personal control in open-plan work environments is an important means to alleviating adverse perceptions. Noise due to conversations and phone calls negatively affected the controlling perception, which was expected as people cannot control themselves the level of noise. Around one-third of the occupants reported negative perception of lighting control, which is similar to findings by Moore et al. [50]. Boardass et al. [18] and Toftum [21] also indicated that the perceived degree of controlling parameters (temperature, ventilation, lighting) decreases with the increased number of occupants inside offices. To some extent, it seems that occupants perceive controlling capabilities better when providing them with the feeling of freedom inside the office buildings. Effort-Reward Imbalance (ERI), which is a critical psychological parameter in office environments, significantly affected control perception and the occupants' perceived comfort inside offices [36]. Moreover, occupants who habitually use air fresheners in their home seem to be more sensitive to adjusting their indoor work environment. The psychological aspect of perceived control is reinforced, as observed by Luo et al. [25].

A significant positive but weak correlation was observed between perceived control and perceived comfort. This finding is in compliance with Boerstra et al. [23], Haghighat and Donnini [19] and Roulet et al. [51]. This work includes a deeper analysis of the appreciation of the perceived control. It should be noted that the analysis using the combined control parameters is not widely used in this type of studies. Combined scores of the controlling parameters were positively correlated with IEQ satisfaction, as Boerstra et al. [23] also found. However, in our study, the combined control perception affected with a stronger correlation the overall comfort, in contrast to the findings of Boerstra et al. [23]. This could be explained by the fact that occupants with higher combined control perception perceive overall comfort with more satisfaction. Combined control perception also resulted in occupants being more satisfied with the overall air quality as well as with the amount of privacy and office layout. In general, occupants who are more able to adjust their environment feel more satisfied.

Regarding building-related health symptoms, the combined scores unveil higher negative correlations with the PSI5. Office occupants reported less health symptoms related to buildings where they perceived higher degree of personal controls.

\subsection{Strengths and Limitations}

This study has several strengths: a relatively large sample size, a survey performed in different geographical areas across Europe, and the use of standardized procedures (questionnaire and checklist). Data on socio-demographics, psycho-social work environment, and perceived environmental quality were collected by a validated questionnaire. IEQ was assessed using both crude IEQ items (satisfaction with perceived control over temperature, ventilation, shading from the sun, light and noise, as well as satisfaction with overall thermal comfort, noise, light, and indoor air quality), and with 14 detailed indoor environmental parameters (e.g., layout, noise within the building, noise from building systems, noise outside the building, air movement). Some limitations, however, should be noted. Caution is needed when interpreting results, because data on IEQ were self-reported. Consequently, a potential (recall) bias cannot be excluded and this type of surveys do not always capture IEQ issues. A combination of objective and subjective measurements would be useful for 
assessing IEQ. Another limitation is the cross-sectional study design. Therefore, no causality of the identified relations can be confirmed.

\section{Conclusions}

The following conclusions can be drawn from the present study:

1. In general, occupants have a moderate or low access in the control of their indoor working environment. They have rated with a moderate control perception the lighting and shading from the sun parameters. Noise was the worst control parameter, while temperature and ventilation control were rated in the low control scale. Among the five control parameters, there was a significant group of occupants who were not able to control their environment at all. Nearly all occupants have no or low control on noise. Half of the occupants declared no or low control on ventilation and temperature conditions. Almost one-third of them remarked that they do not have satisfactory levels of control for lighting and shading from sun conditions. It is noteworthy that as the occupancy within the offices increases, the degree of personal control becomes lower.

2. Occupants with a higher level of personal control were reported to be more productive within their working environment. Moreover, occupants who declared high degrees of personal control reported higher levels of IEQ satisfaction.

3. Some significant correlations were found between the available controls within the building and the perceived control. The availability of operable windows had a higher impact on the occupants' control perception over temperature, ventilation, light and noise than floor area or occupancy. Perceived control over temperature differed significantly with the different types of solar devices.

4. Occupants' perceived control is related to psychological aspects. General building characteristics, such as floor number and floor area, office type, operable windows, etc., which help occupants feel freedom were positively associated with the perceived control. ERI remains a significant parameter of the controlling perception in office environments.

5. Concerning the impact of perceived control on perceived comfort, the results of the present study are in general agreement with the literature. More specifically:

- The perceived combined control over all studied parameters is positive on the overall comfort

- The combined control over all parameters seems to have a stronger effect on overall comfort than the single controls

- Temperature variation seems to be more related to the combined control of temperature and shading from the sun control

- Combined control perception over temperature, ventilation and shading positively affects the occupants and gives them the feeling of fresher air and an overall satisfaction with air quality

- Noise from the buildings systems seems to be more affected by the combined control perception of all parameters rather than single controls

- The combined perceived control of all parameters was found to affect the occupants' privacy, office layout and decoration satisfaction more

6. Regarding reported health symptoms, office occupants with a higher degree of personal controls reported less building-related health symptoms.

Author Contributions: Conceptualization, I.S., D.S., C.M. and J.B.; data curation, I.S.; formal analysis, I.S.; funding acquisition, J.B.; investigation, I.S., D.S., C.M., Y.d.K., S.F., A.S., A.C., T.S. and V.M.; methodology, I.S., C.M., Y.d.K. and J.B.; project administration, J.B.; resources, K.K.; supervision, D.S. and J.B.; visualization, I.S.; writing-original draft, I.S.; writing-review \& editing, D.S., C.M., Y.d.K., S.F., A.S., A.C., T.S., V.M., E.d.O.F., K.K., P.C. and J.B.

Funding: This research was funded by the European Union 7th 427 Framework, grant number Agreement 265267 under Theme: ENV.2010.1.2.2-1. 
Acknowledgments: This work was supported by the project "OFFICAIR" (On the Reduction of Health Effects from Combined Exposure to Indoor Air Pollutants in Modern Offices).

Conflicts of Interest: The authors declare no conflict of interest.

\section{References}

1. Huang, Y.-H.; Robertson, M.M.; Chang, K.-I. The Role of Environmental Control on Environmental Satisfaction, Communication, and Psychological Stress: Effects of Office Ergonomics Training. Environ. Behav. 2004, 36, 617-637. [CrossRef]

2. Gee, G.C.; Payne-Sturges, D.C. Environmental Health Disparities: A Framework Integrating Psychosocial and Environmental Concepts. Environ. Health Perspect. 2004, 112, 1645-1653. [CrossRef]

3. Kalimeri, K.K.; Saraga, D.E.; Lazaridis, V.D.; Legkas, N.A.; Missia, D.A.; Tolis, E.I.; Bartzis, J.G. Indoor air quality investigation of the school environment and estimated health risks: Two-season measurements in primary schools in Kozani, Greece. Atmos. Pollut. Res. 2016, 7, 1128-1142. [CrossRef]

4. Lee, S.Y.; Brand, J.L. Effects of control over office workspace on perceptions of the work environment and work outcomes. J. Environ. Psychol. 2005, 25, 323-333. [CrossRef]

5. Huizenga, C.; Abbaszadeh, S.; Zagreus, L.; Arens, E.A. Air quality and thermal comfort in office buildings: Results of a large indoor environmental quality survey. Proceeding Healthy Build. 2006, 3, 393-397.

6. Brager, G.; Baker, L. Occupant satisfaction in mixed-mode buildings. Build. Res. Inf. 2009, 37, 369-380. [CrossRef]

7. Langevin, J.; Wen, J.; Gurian, P.L. Relating occupant perceived control and thermal comfort: Statistical analysis on the ASHRAE RP-884 database. HVACER Res. 2012, 18, 179-194.

8. Vine, E.; Lee, E.; Clear, R.; DiBartolomeo, D.; Selkowitz, S. Office worker response to an automated Venetian blind and electric lighting system: A pilot study. Energy Build. 1998, 28, 205-218. [CrossRef]

9. Lee, S.Y.; Brand, J.L. Can personal control over the physical environment ease distractions in office workplaces? Ergonomics 2010, 53, 324-335. [CrossRef]

10. Samani, S.A. The Impact of Personal Control over Office Workspace on Environmental Satisfaction and Performance. J. Soc. Sci. Humanit. 2015, 1, 163-172.

11. Xuan, X. Study of indoor environmental quality and occupant overall comfort and productivity in LEEDand non-LEED-certified healthcare settings. Indoor Built Environ. 2018, 27, 544-560. [CrossRef]

12. Yun, G.Y. Influences of perceived control on thermal comfort and energy use in buildings. Energy Build. 2018, 158, 822-830. [CrossRef]

13. Zhao, Z.; Amasyali, K.; Chamoun, R.; El-Gohary, N. Occupants' Perceptions about Indoor Environment Comfort and Energy Related Values in Commercial and Residential Buildings. Procedia Environ. Sci. 2016, 34, 631-640. [CrossRef]

14. Al horr, Y.; Arif, M.; Katafygiotou, M.; Mazroei, A.; Kaushik, A.; Elsarrag, E. Impact of indoor environmental quality on occupant well-being and comfort: A review of the literature. Int. J. Sustain. Built Environ. 2016, 5, 1-11. [CrossRef]

15. Frontczak, M.; Schiavon, S.; Goins, J.; Arens, E.; Zhang, H.; Wargocki, P. Quantitative relationships between occupant satisfaction and satisfaction aspects of indoor environmental quality and building design. Indoor Air 2012, 22, 119-131. [CrossRef]

16. Paciuk, M. The Role of Personal Control of the Environment in Thermal Comfort and Satisfaction at the Workplace; University of Wisconsin-Milwaukee: Milwaukee, WI, USA, 1989.

17. Collins, B.L.; Fisher, W.; Gillette, G.; Marans, R.W. Second-Level Post-Occupancy Evaluation Analysis. J. Illum. Eng. Soc. 1990, 19, 21-44. [CrossRef]

18. Bordass, B.; Bromley, K.; Leaman, A. User and Occupant Controls in Office Buildings; BRE: Brussels, Belgium, 1993; p. 13.

19. Haghighat, F.; Donnini, G. Impact of psycho-social factors on perception of the indoor air environment studies in 12 office buildings. Build. Environ. 1999, 34, 479-503. [CrossRef]

20. Zweers, T.; Preller, L.; Brunekreef, B.; Boleij, J.S.M. Health and Indoor Climate Complaints of 7043 office Workers in 61 Buildings in the Netherlands. Indoor Air 1992, 2, 127-136. [CrossRef]

21. Toftum, J. Central automatic control or distributed occupant control for better indoor environment quality in the future. Build. Environ. 2010, 45, 23-28. [CrossRef] 
22. Zagreus, L.; Huizenga, C.; Arens, E.; Lehrer, D. Listening to the occupants: A Web-based indoor environmental quality survey. Indoor Air 2004, 14, 65-74. [CrossRef]

23. Boerstra, A.; Beuker, T.; Loomans, M.; Hensen, J. Impact of available and perceived control on comfort and health in European offices. Archit. Sci. Rev. 2013, 56, 30-41. [CrossRef]

24. Kwon, M.; Remøy, H.; van den Dobbelsteen, A.; Knaack, U. Personal control and environmental user satisfaction in office buildings: Results of case studies in the Netherlands. Build. Environ. 2019, 149, 428-435. [CrossRef]

25. Luo, M.; Cao, B.; Ji, W.; Ouyang, Q.; Lin, B.; Zhu, Y. The underlying linkage between personal control and thermal comfort: Psychological or physical effects? Energy Build. 2016, 111, 56-63. [CrossRef]

26. Karjalainen, S. Thermal comfort and use of thermostats in Finnish homes and offices. Build. Environ. 2009, 44, 1237-1245. [CrossRef]

27. De Dear, R.; Brager, G.S. Developing an Adaptive Model of Thermal Comfort and Preference. ASHRAE Trans. 1998, 104, 1-18.

28. ASHRAE Standard 55 Thermal Environmental Conditions for Human Occupancy; ANSI/ASHRAE: Atlanta, GA, USA, 2013.

29. International Organization for Standardization ISO 7730:2005. Available online: http://www.iso.org/cms/ render/live/en/sites/isoorg/contents/data/standard/03/91/39155.html (accessed on 26 July 2019).

30. Olesen, B.W.; Parsons, K.C. Introduction to thermal comfort standards and to the proposed new version of EN ISO 7730. Energy Build. 2002, 34, 537-548. [CrossRef]

31. OFFICAIR Project. Available online: http://www.officair-project.eu/ (accessed on 6 August 2019).

32. Nørgaard, A.W.; Kofoed-Sørensen, V.; Mandin, C.; Ventura, G.; Mabilia, R.; Perreca, E.; Cattaneo, A.; Spinazzè, A.; Mihucz, V.G.; Szigeti, T.; et al. Ozone-initiated Terpene Reaction Products in Five European Offices: Replacement of a Floor Cleaning Agent. Environ. Sci. Technol. 2014, 48, 13331-13339. [CrossRef]

33. Mihucz, V.G.; Szigeti, T.; Dunster, C.; Giannoni, M.; de Kluizenaar, Y.; Cattaneo, A.; Mandin, C.; Bartzis, J.G.; Lucarelli, F.; Kelly, F.J.; et al. An integrated approach for the chemical characterization and oxidative potential assessment of indoor PM2.5. Microchem. J. 2015, 119, 22-29. [CrossRef]

34. Bluyssen, P.M.; Roda, C.; Mandin, C.; Fossati, S.; Carrer, P.; de Kluizenaar, Y.; Mihucz, V.G.; de Oliveira Fernandes, E.; Bartzis, J. Self-reported health and comfort in 'modern' office buildings: First results from the European OFFICAIR study. Indoor Air 2016, 26, 298-317. [CrossRef]

35. De Kluizenaar, Y.; Roda, C.; Dijkstra, N.E.; Fossati, S.; Mandin, C.; Mihucz, V.G.; Hänninen, O.; de Oliveira Fernandes, E.; Silva, G.V.; Carrer, P.; et al. Office characteristics and dry eye complaints in European workers-The OFFICAIR study. Build. Environ. 2016, 102, 54-63. [CrossRef]

36. Sakellaris, I.; Saraga, D.; Mandin, C.; Roda, C.; Fossati, S.; de Kluizenaar, Y.; Carrer, P.; Dimitroulopoulou, S.; Mihucz, V.; Szigeti, T.; et al. Perceived Indoor Environment and Occupants' Comfort in European “Modern" Office Buildings: The OFFICAIR Study. Int. J. Environ. Res. Public Health 2016, 13, 444. [CrossRef]

37. Szigeti, T.; Dunster, C.; Cattaneo, A.; Cavallo, D.; Spinazzè, A.; Saraga, D.E.; Sakellaris, I.A.; de Kluizenaar, Y.; Cornelissen, E.J.M.; Hänninen, O.; et al. Oxidative potential and chemical composition of PM2.5 in office buildings across Europe-The OFFICAIR study. Environ. Int. 2016, 92-93, 324-333. [CrossRef]

38. Campagnolo, D.; Saraga, D.E.; Cattaneo, A.; Spinazzè, A.; Mandin, C.; Mabilia, R.; Perreca, E.; Sakellaris, I.; Canha, N.; Mihucz, V.G.; et al. VOCs and aldehydes source identification in European office buildings-The OFFICAIR study. Build. Environ. 2017, 115, 18-24. [CrossRef]

39. Mandin, C.; Trantallidi, M.; Cattaneo, A.; Canha, N.; Mihucz, V.G.; Szigeti, T.; Mabilia, R.; Perreca, E.; Spinazzè, A.; Fossati, S.; et al. Assessment of indoor air quality in office buildings across Europe-The OFFICAIR study. Sci. Total Environ. 2017, 579, 169-178. [CrossRef]

40. Szigeti, T.; Dunster, C.; Cattaneo, A.; Spinazzè, A.; Mandin, C.; Le Ponner, E.; de Oliveira Fernandes, E.; Ventura, G.; Saraga, D.E.; Sakellaris, I.A.; et al. Spatial and temporal variation of particulate matter characteristics within office buildings-The OFFICAIR study. Sci. Total Environ. 2017, 587-588, 59-67. [CrossRef]

41. Raw, G.J.; Roys, M.S.; Whitehead, C.; Tong, D. Questionnaire design for sick building syndrome: An empirical comparison of options. Environ. Int. 1996, 22, 61-72. [CrossRef]

42. Theodorsson-Norheim, E. Kruskal-Wallis test: BASIC computer program to perform nonparametric one-way analysis of variance and multiple comparisons on ranks of several independent samples. Comput. Methods Programs Biomed. 1986, 23, 57-62. [CrossRef] 
43. Gelman, A.; Hill, J. Data Analysis Using Regression and Multilevel/Hierarchical Models; Cambridge University Press: Cambridge, UK, 2007; ISBN 978-0-521-68689-1.

44. Goldstein, H. Multilevel Statistical Models; John Wiley \& Sons: West Sussex, UK, 2011; ISBN 978-1-119-95682-2.

45. Mukaka, M. A guide to appropriate use of Correlation coefficient in medical research. Malawi Med. J. 2012, 24, 69-71.

46. IBM SPSS Statistics for Windows; Version 22.0; IBM: Armonk, NY, USA, 2013.

47. Brager, G.; Paliaga, G.; de Dear, R.; Olesen, B.; Wen, J.; Nicol, F.; Humphreys, M. Operable Windows, Personal Control, and Occupant Comfort. ASHRAE Trans. 2004, 110, 17-35.

48. Raja, I.A.; Nicol, J.F.; McCartney, K.J.; Humphreys, M.A. Thermal comfort: Use of controls in naturally ventilated buildings. Energy Build. 2001, 33, 235-244. [CrossRef]

49. Gou, Z.; Zhang, J.; Shutter, L. The Role of Personal Control in Alleviating Negative Perceptions in the Open-Plan Workplace. Buildings 2018, 8, 110. [CrossRef]

50. Moore, T.; Carter, D.; Slater, A. User attitudes toward occupant controlled office lighting. Light. Res. Technol. 2002, 34, 207-216. [CrossRef]

51. Roulet, C.-A.; Johner, N.; Foradini, F.; Bluyssen, P.; Cox, C.; De Oliveira Fernandes, E.; Müller, B.; Aizlewood, C. Perceived health and comfort in relation to energy use and building characteristics. Build. Res. Inf. 2006, 34, 467-474. [CrossRef]

(C) 2019 by the authors. Licensee MDPI, Basel, Switzerland. This article is an open access article distributed under the terms and conditions of the Creative Commons Attribution (CC BY) license (http://creativecommons.org/licenses/by/4.0/). 